\title{
1. Giovanni Botero (1588) and Antonio Serra (1613): Italy and the birth of development economics Erik S. Reinert*
}

Secretary of State George Marshall got it right in his June 1947 Harvard speech when announcing what later was to be called the Marshall Plan: 'There is a phase of this matter which is both interesting and serious. The farmer has always produced the foodstuffs to exchange with the city dweller for the other necessities of life. This division of labor is the basis of modern civilization'.

The Marshall Plan - a plan to re-industrialize Germany and later the rest of Europe came as a substitute for the Morgenthau Plan, the goal of which had been the exact opposite: to de-industrialize Germany to prevent further wars. The arguments for discontinuing the Morgenthau Plan were forcefully made by President Truman's envoy to Germany, former President Herbert Hoover. In his letter a few months earlier Hoover had pointed to the key link between a nation's economic structure and the number of people it can carry: 'There is the illusion that the New Germany left after the annexations can be reduced to a 'pastoral state'. It cannot be done unless we exterminate or move 25000000 out of it'.

Marshall and Hoover go to the core of economic development, reviving a long tradition that explains development and population density with the economic activities found in cities. In his 1588 treatise On the Greatnesse of Cities Giovanni Botero describes why the few islands of generalized wealth at the time were found in cities with their large division of labour, technical change, and the high value added given to imported raw materials. In 1613, Antonio Serra adds the argument that the core of the virtuous circles of growth is found in increasing returns to scale. As we shall see, Botero's intellectual impact on Europe in the 1600s was formidable, but now not recognized, while Serra who provided the theoretical explanation - was virtually forgotten until his work was briefly rediscovered in the 1750 s.

When World Bank Chief Economist Justin Yifu Lin recently wrote, 'Except for a few oil-exporting countries, no countries have ever gotten rich without industrialization first' (Lin 2012, 350), he is essentially only confirming Botero's and Serra's point. Functional theories of economic development, including those of United States (US) Secretary of the Treasury Alexander Hamilton (1791), German economist Friedrich List (1841), who provided continental Europe's rationale for industrialization, and post-World War II (WWII) classical development economics - whether they were recognized or not $^{2}$ - were all based on the principles first observed by Botero and theorized by Serra as being

* This chapter is the result of a long cooperation with my son Sophus A. Reinert. The usual disclaimer applies.

Hoover's Report No. 3, 18 March 1947, quoted in Baade (1955)

Friedrich List referred to Serra, whose book had been republished in 1803, but not to Botero. 


\section{Handbook of alternative theories of economic development}

the result of cumulative causations originating in increasing returns. As this volume is going to press (July 2016), the newly appointed World Bank Chief Economist - Paul Romer - again resurrects and confirms - but without reference - the approach and the theories first developed by Giovanni Botero and Antonio Serra: using 'the city as a unit of analysis' ${ }^{3}$ and finding development to be the result of human industrial agglomeration.

On the other hand, the diminishing returns found in agriculture and the extraction of raw materials have provided pessimism, from Thomas Malthus (1798) to Alfred Marshall, the founder of neoclassical economics, who in his 1890 Principles of Economics pointed to diminishing returns as 'the cause of most migrations of which history tells' (Marshall 1890, 201).

Probably inspired by Malthus, nineteenth-century classical economists, such as John Stuart Mill, were acutely aware of the importance of diminishing returns:

I apprehend [the elimination of diminishing returns] to be not only an error, but the most serious one, to be found in the whole field of political economy. The question is more important and fundamental than any other; it involves the whole subject of the causes of poverty ... and unless this matter be thoroughly understood, it is to no purpose proceeding any further in our inquiry. (Mill 1848, 176)

Ex-President Herbert Hoover, quoted above, testified to the fact that killing increasing returns industries - manufacturing - would lead to the migration, or even worse, the extermination of 25 million people in post-WWII Germany.

I would argue that the lost connection between economic structure and population density is perhaps the biggest elephant in the room of today's economic academia. We find that the de-industrialization of many Third World countries, as civil war and bombs and/or premature free trade destroy manufacturing, produces mass migration. The only long-term solution to the surging refugee problem is to recognize the wisdom of George Marshall and Herbert Hoover: reindustrialize in order to re-create civilization and increase the carrying capacity of the Third World to create livable conditions for its own population.

In their Communist Manifesto, Marx and Engels also emphasize the importance of towns and cities:

The bourgeoisie has subjected the country to the rule of the towns. It has created enormous cities, has greatly increased the urban population as compared with the rural, and has thus rescued a considerable part of the population from the idiocy of rural life. Just as it has made the country dependent on the towns, so it has made barbarian and semi-barbarian countries dependent on the civilized ones, nations of peasants on nations of bourgeois, the East on the West. (Marx and Engels 1848, Ch. 1)

As alluded to in the Introduction to this volume, the isomorphisms, the structural similarities, between both political sides of the Cold War - the historical insistence on industrialization and on the control of the financial sector - are key elements that were unlearned during the market triumphalism following the 1989 fall of the Berlin Wall. ${ }^{4}$ In bank/.

This approach is described in https://paulromer.net/my-new-position-as-chief-economist-at-the-world-

4 I have pointed to the cyclical nature of economics in this aspect (Reinert 2012). 
this chapter I shall discuss Giovanni Botero and Antonio Serra as pioneer development economists, but first it is necessary to look at the context in which their ideas arose.

\section{'OUT OF ITALY'}

The importance of cities for modern civilization has a long history that can only be very briefly sketched here. ${ }^{5}$ During the eighteenth and nineteenth centuries so-called stage theories of economic development were very prominent; some even argue that these theories were a foundation stone for economics itself (Meek 1976). The normal stages were seen as: (1) the Age of Hunting; (2) the Age of Pastoralism; (3) the Age of Agriculture; and (4) the Age of Agriculture and Manufacturing. In the teachings of German economist Karl Bücher (1847-1930), these different stages - different forms of social livelihood - were accompanied by different forms of human social organization. The first stages were dominated by family economy and clan economy, where Karl Polanyi's fictitious commodities of capitalism - private ownership of land, labour as a commodity, and money - are absent. It is only with the town economy that capitalism develops. Bücher, as did Polanyi, places great emphasis on the fact that the division of labour existed inside the family, clan economies and in aristocratic households long before there were markets. The city-centred theories of development can be traced back to Arab historian Ibn Khaldun (1332-1406), who produced a cyclical theory of history where desert tribes conquer cities, only to decay over time and become the prey of a fresh group of nomads, who undergo the same experience. Cyclical theories were typically zero-sum games that only with the Renaissance gave way to the possibility of progress.

At the core of stage theories is that the mode of production - that is, whether you are in the Stone Age or the Computer Age - will determine your institutional structure. In the stage tradition of Karl Bücher, the structure of production tends to influence the institutional structure more than the other way around. ${ }^{6}$ Working both with pastoralism in the high Andes and with Saami reindeer herders in Northern Fennoscandia, I can testify to the striking similarities in the social organization of pastoralists from so different areas and cultures. Ibn Khaldun, like Bücher, saw that 'The differences between different peoples arise out of the differences in their occupations'. ${ }^{7}$ This observation tends to reverse the arrows of causality in economic development compared to the formal theorizing in modern institutional economics, for example Acemoglu and Robinson (2012). ${ }^{8}$ I

For an overview see Reinert (2000b, 177-222).

6 This view is largely compatible with Diamond (1997). Anthropologists argue that the institution of cannibalism tends to appear in environments with limited sources of animal protein, for example in Central America and the Caribbean. The conditions create the institutions, not the other way around.

Ibn Khaldun quoted in Issawi $(1987,17)$.

8 In their criticism of Diamond, Acemoglu and Robinson (2012, pp. 51-53) show what might be their weakest point. When explaining that 'North America became more prosperous [than Peru and Mexico] precisely because it enthusiastically adopted the technologies and the advances of the Industrial Revolution' (p. 53), the authors leave out that Peru and Mexico for a long time were colonies, and later de facto colonies, as power just shifted from Spaniards in Spain to Spaniards - with the same vested interests in exporting raw material - in the former colonies. The key characteristic of a colony was that manufacturing was prohibited. That the United States was prohibited from manufacturing most things other than tar and timber for masts was an important reason for the 13 colonies wanting independence from Britain in 1776. The right for the necessary protection of 
would argue, in the Bücher tradition, that the Venetians did not invent an official property register (catasto), around 1150, later to create capitalism, but rather because the capitalist growth of the city created a need for the property register. Likewise, one could argue that the Venetians did not invent insurance, and then, based on this, start long-distance trading. Rather, one could argue that the previous system of spreading risk through ever smaller percentages of ownership of ships and cargo became impracticable because of the many owners, and that the impracticability of this fractionalized ownership is at the origin of a system of insurance: risk is being spread without spreading ownership. In practice, economic activities and their institutions co-evolve, and the first geographical area where this process of co-evolution created capitalism was in the Italian city-states starting in the twelfth century. ${ }^{9}$

The principle that economic modes of production influence the creation of institutions more than the other way around forms the core of what I refer to as 'Other Canon Economics', and has very important practical consequences. In 2014, on one of two visits to Zimbabwe, in conversations with key policy-makers under the influence of the Washington Consensus, I observed that their policy was to attempt to change institutions without changing the economic structure. This approach totally disregards that most African countries reflect a pre-capitalist clan structure that Europe only got rid of by creating city activities and industrialization. It is very unlikely that Africa can create a genuine institutional change without first changing its economic structure. This has simply never been done before.

Changes of national economic structures have invariably been a result of policies involving import substitution and tariffs. England protected its economy for 300 years, South Korea for perhaps only 40, but economic policy has always been a key element in economic transformation. Sometimes this economic policy has been conscious and voluntary, as with the Tudor strategy shifting England's comparative advantage from the export of raw wool to the export of woollen cloth. This started with Henry VII in 1485 and in the end, under Elizabeth I, prohibited the export of raw wool from England (Reinert 2007). Sometimes the 'natural' protection of time, distance and transportation costs has been important, as in the early industrialization of Australia and New Zealand. In other cases, the import substitution policies have been imposed from the outside, as during the collapse in US imports during the blockades of the Napoleonic Wars, and in the case of the rapid industrialization of Southern Rhodesia, present-day Zimbabwe, as a result of the country being boycotted due to apartheid. ${ }^{10}$

What marks the start of what we call development economics? Clearly, systematic attempts to understand society in order to increase its wealth started during the

new technologies had to be won twice in the United States: first in 1776 and then with the Civil War, where the South wanted free trade. As my short history of Latin America has been for decades: 'Latin America is a group of countries where the South won the Civil War'. By disregarding the history of economic policy - that prohibiting manufacturing was generally at the core of colonial policies - Acemoglu and Robinson tend to blame the present elites of the Third World for conditions that historically have been imposed upon their countries by First World imperialism. In a sense they blame the victims. For a criticism of Acemoglu and Robinson from a historian's viewpoint, see Vries (2012). See also a discussion in the Epilogue, Chapter 40 in this volume.

9 The massive work on Der Moderne Kapitalismus by Werner Sombart (1863-1941), on which Braudel partly rests, will in 2016 be published for the first time in a full English translation of the 1916 six-volume edition as Modern Capitalism (1916) (Sombart forthcoming [1916]).

10 Manufacturing as percentage of gross domestic product (GDP) rose to more than 30 per cent. 
Renaissance - literally, the rebirth - of the cultural traditions of classical society. This tradition, to cite the title of one of Fernand Braudel's books, came 'out of Italy' (Braudel 1991; see also Braudel 1975). This may sound like an innocuous proposition, but at a 2008 State of the Planet conference at Columbia University, to which Jeffrey Sachs had invited me, I found it was not. When I mentioned this fact during my talk, Professor Sachs arose in an audience of several hundred people and virtually screamed at me that this was not true, capitalism was born in England.

Professor Sachs's reaction is part of the Anglo-Saxon bias that we refer to in the Introduction to this volume. This is a myth similar to those created also earlier in history. The Roman Empire clearly built on previous local cultures, the Etruscan culture being the most important, but in order to obliterate any debt to previous civilizations the Romans created the myth of the city being founded by Romulus and Remus who were brought up by la lupa (the she-wolf). The relatively short-lived Inca Empire, essentially a forced political integration of several advanced agricultural societies, created a similar myth among many: the first Inca, Manco Capac, and his sister-wife Mama Ocllo, emerged from Lake Titicaca and founded the Empire. Unfortunately the Adam Smith myth plays a similar role in the minds of most modern economists: civilization started with the English-speaking world.

Capitalism came out of Italy in the sense that capitalism was born in the Italian citystates. As probably the most important historian of capitalism, Werner Sombart, puts it, the defining feature of capitalism is neither private property nor the division of labour, it is the fact that accumulation does not stop when the needs of the immediate family have been met. Capitalism has an element of magna facere - of doing great things beyond immediate need - about it. A curious example of this could be observed in Bologna in the 1100 s and 1200 s. Over a relatively short period more than 180 huge towers were erected in the city (Roversi 1989). Despite their appearance of military might, the towers of Bologna would only have been of limited military use, due in part to their suffocating proximity to each other. The towers were true, pure monuments in themselves. Behind this fanatical building spree, there was the need for the richest local families to display their power and might, as they competed against each other in the papal/imperial investiture controversy. ${ }^{11}$ In Thorstein Veblen's terminology, Man's 'instinct of workmanship' was allowed to flourish in this display of 'emulation' 12 among wealthy families of Bologna in their 'conspicuous consumption'. ${ }^{13}$ At the same time their 'parental bent' secured the construction of livable societies. The tower fury can also be seen as an early case of what Albert Hirschman describes as economic ambition - in this case competing through the building of towers - introduced as a substitute for passions in the form of warfare (Hirschman 1977, 134.) As a necessary part of this Renaissance development came a set of bourgeoisie values first codified by the Florentine scholar Leon Battista

\footnotetext{
11 The war between the Guelfs and the Ghibellines plagued the Italian peninsula at the time.

12 It is important to note that the instinct of emulation in many cases will lead to the exact opposite recommendation from that of David Ricardo's comparative advantage. If a Stone Age tribe discovers that the tribe across the river has discovered a new material and moved into the Bronze Age, Veblen's type of analysis will recommend them to follow into the Bronze Age by emulation, while Ricardo will tell them to stick to their comparative advantage in the Stone Age.

${ }_{13}$ For a discussion of Veblen as a development economist see Reinert and Viano (2012).
} 
Alberti (1404-1472) ${ }^{14}$ and later made famous in the writings of Benjamin Franklin (1706-1790), ${ }^{15}$ whose Way to Wealth, reaching more than 1100 editions before 1850 , no doubt is the top economic bestseller in history. ${ }^{16}$

The inspiration came from classical Greek texts. Many of them, surviving because they had been translated into Arabic in the great translation factory that was Baghdad around 800, were translated into Latin. Xenophon (c.430-355 BC), whose works were brought from Byzantium to Italy in 1427, gave us the term economics from his work on household management: Oeconomicus. Together with Aristotle, this work had considerable influence on the evolution of Scholastic economic thought through a text by Xenophon written around the year $352 \mathrm{BC}$ : Poroi - On the Ways and Means of Improving the Revenues of the State of Athens. The influence of the Poroi has never been well charted. ${ }^{17}$

Xenophon sought both to explain and to remedy the ongoing balance-of-payments crisis that Athens had suffered as a consequence of the so-called 'Social War' against its former allies (Isocrates $355 \mathrm{BC}$, Verse 19). Xenophon refers to what we could call 'systemic increasing returns' when, in the Poroi, he suggests that certain problems in a city can be solved by making the city larger.

Italian economic historian (and many times Prime Minister) Amintore Fanfani encapsulated, without explaining, the shift explored here: 'while scholasticism thinks of an order in equilibrium, mercantilism thinks of an order in growth' ${ }^{18}$ In a sense, neoclassical economics returned to a view more similar to scholasticism (Reinert 2000a).

\section{INFINITE COSMOLOGY: THE POSSIBILITY OF PROGRESS AND THE END OF ZERO-SUM SOCIETY}

When George Soros claimed that 'Globalization is not a zero sum game' (Soros 2002, 9) he unwittingly touched upon the very problem that faced economic thinkers at the end of the Renaissance, as they indeed feared that it was a zero-sum game. The modern conception of history and economics reflected in Soros's statement is entirely dependent on our cosmological conception of time as a vector of progress, as a linear force that potentially brings never-ending change in a space of infinite resources. Starting in the Renaissance production-centred economics - in what I refer to as The Other Canon - economic thought has been intimately intertwined with this idea of a historical progress with infinite possibilities; it indeed forms the very framework of economic thinking from the earliest stage theories to the contemporary neo-Schumpeterian approach. This conception of time is, however, a relatively recent development in what Veblen calls 'the life-history of our species'. 'Time' was for the longest time thought of in very different terms. The

\footnotetext{
14 The first modern publication of his work on this is Alberti (1734). On Alberti see Grafton (2000).

15 For the classical discussion on the values of capitalism, see Sombart (1913). Sombart discusses both Alberti and Franklin.

16 See http://waytowealth.org (accessed 25 September 2015). For a discussion on Franklin's work, see S. Reinert (2015).

17 The Latin phrase indicates that Aurispa brought the entirety of Xenophon's corpus with him from Byzantium: 'omnia quicquid scripsit' (Baron 1938; Sombart 1913; Bruni 1987, 300-311).

18 In Italian: 'mentre lo scolasticismo pensa ad un ordine in equilibrio, il mercantilismo pensa ad un ordine in accrescimento' (Fanfani 1955, 149).
} 
idea of economic progress is thus quite intertwined with the modern idea of time as an indicator of change, as well as the idea of spatial infinity following from the heresies of the 1500s: of the ideas of Copernicus, Bruno and Galileo.

The world was seen as being a finite place, a locked system in cosmic equilibrium. This zero-sum model of the universe was an Aristotelian invention (Aristotle, Politics vii, ix, 3, 1328b), channelled by St Jerome (c.340-420) and Thomas Aquinas (c.1225-1274). The early 'balance of trade' was strongly related to the theory that 'one man's gain must be another man's loss'. ${ }^{19}$ The same idea appeared again in Switzerland as an essential part of Paracelsus' work (c.1493-1541). Being a cosmologist rather than a scientist, Paracelsus' hermetic tradition had an enormous influence on the reigning episteme, and the influence of his work indeed echoed across Europe into the seventeenth century and beyond (Paracelsus 1951, 38-44). In France, Michel de Montaigne (1533-1592) argued in his 1580 Essays that 'no profit can be made except at another's expense, and so by this rule we should condemn any sort of gain' (Montaigne 1958 [1580], 48). Similarly, England saw Sir Thomas Browne's (1605-1682) 1643 Religio Medici hold that 'all cannot be happy at once for, because the glory of one state depends upon the ruins of another, there is a revolution and vicissitude of their greatness' (Browne 1643, Book I, xvii). The zero-sum view of the economy was a pan-European phenomenon.

This is, of course, not to say that there were no earlier exponents of various aspects of this change. Indeed, positive-sum undercurrents are identifiable across the European mindscape throughout the Middle Ages, and the importance of time for economic gain was already present in explicit form in the tenth-century Colloquy of Ælfric of Eynsham (Wood 2002, 117). It was, rather, the cumulative culmination of a number of these correlated factors - the new cosmology, the change in religious outlook, the understanding of an extension of the synergetic common good - that constituted the epistemic shift which made innovation into something desirable rather than something heretic and threatening to God's plans.

\section{INFINITE COSMOLOGY: RELIGIOUS CAUSES AND EFFECTS}

In a previous co-authored paper, I have treated in detail the religious aspects of the Renaissance as they relate to the birth of innovations (Reinert and Daastøl 1997). I shall summarize the most important features here.

The emerging neo-Platonic world saw all creation in the spirit of God; it was pantheistic. The philosophers of this creed pointed out the need to explore and to better understand Nature as a necessary way to know God. They conveyed an image of God as active, rational and creative. Since Man was created in the image of God, the human being also had the potential for these same qualities, both as individuals and collectively as a 'social body'. This permission to seek new knowledge - to learn, explore, invent and educate - soon developed into a duty to do so. Creation was not ended on the seventh day, it was God's will that man should be creative in order to improve on the creation, and thereby improve both his own condition and that of his fellow human beings, all the

19 St Jerome, cited in Finkelstein (2000, 89). 
members of the social body of society. It was our duty to populate the Earth, so the Lord had built in an incentive system for procreation. Likewise, the Continental philosophers in the tradition of Leibniz (1646-1716) and Christian Wolff (1679-1754) would argue, the fact that it was so satisfactory to discover new things and understand the world better was a proof of our duty to do so. It became Man's pleasurable duty to explore, discover, invent and innovate.

This transition was not frictionless or painless. A forerunner of these thoughts, Nicolas of Cusa (1401-1464), the German-born Bishop of Brixen (Bressanone), now in Italy, suffered persecution. Giordano Bruno, one of his spiritual followers, was burned at the stake in Rome in the year 1600. Bruno laid the foundations for the works of Kepler, but also for the tradition of Galileo and Newton. The religious persecutions of new knowledge are well known.

The influences from the Byzantine Empire - one of the very few millennium empires the world has ever seen - were very strong in these processes. This applies both to the diffusion of Plato's texts and in the religious redefinition of Man's duties on Earth, no longer as a caretaker in the garden of creation, but as a junior partner in the process itself. The fall of Constantinople to the Turks precipitated an influx of philosophers and texts from the East into Italy, and the presence of these philosophers added much prestige to the Italian city-state courts. The most influential of these Byzantine philosophers was George Gemistos Plethon ${ }^{20}$ (c.1360-1450). It was Plethon's enthusiasm for Platonism that influenced Cosimo de Medici to found a Platonic Academy at Florence, one of the earliest of the academies that were to be so important for the later growth of knowledge in Europe. In 1441, Plethon had returned to the Peloponnesus, and there he died and was buried in 1450 .

Just as the young Republic of Venice snatched the body of San Mark from Alexandria to bury him in Venice, thereby adding to the power and prestige of the city, so the Malatesta family of Rimini had Plethon's body removed from his resting place in the Peloponnesus to the Tempio Malatestiano in Rimini in 1465. There he can still be visited under the inscription of 'Themistius Byzantinus'. From the point of view of innovation systems it is interesting to note that Plethon emphasized the need to stimulate and protect Byzantine industry and economy faced with growing Italian competition (Kazhdan 1991, Vol. I, 637).

\section{RIGHTS BECOME DUTIES: THE BIRTH OF THE 'DEVELOPMENTAL STATE'}

The New Testament values, freeing Christendom from tribal favouritism and from a revengeful and intervening deity of the Old Testament were - in my humble opinion transcendental in developing Europe. The Renaissance was also an example of English historian Richard Tawney's assertion that economic development is mainly a result of less religion, not so much what religion (Tawney 1926). ${ }^{21}$ A main protagonist in

\footnotetext{
20 His enthusiasm for Plato made him change his name to Plethon.

${ }^{21}$ By this I do not mean the disappearance of religious values and ethics or atheism, I simply refer to the reduced religious fervour which normally accompanies the separation of civic and religious life.
} 
the Renaissance, Plethon - mentioned above - was in favour of bringing back the old Olympian Gods, and the whole imagery of Renaissance art profusely reflects this vision. The best and most representative paintings are probably those of Sandro Botticelli (c.1445-1510), whose Primavera and The Birth of Venus exemplify the richness brought about by pagan imagery. In other cultural areas civic humanism came to overshadow strictly religious humanism.

A second tectonic religious shift - following that of the New Testament - is represented by the counterpoint between Girolamo Savonarola (1452-1498) and his CounterReformation (Weinstein 2011) and the Reformation of Martin Luther (1483-1546). Savonarola wanted the old intervening deity reinstated, and to his Bonfires of the Vanities, essentially directed against non-religious culture in most forms, reportedly even Sandro Botticelli brought one of his own paintings to be burned. ${ }^{22}$ For a new assessment of the economic views of Martin Luther see the annotated English translation of his 1524 Trade and Usury (Luther 2015). In his writings on Savonarola, German historian Leopold von Ranke (1795-1886) contrasted the two as follows: 'One of Luther's largest accomplishments for the later development of the world lies in the distinction between civic and religious life. Savonarola wanted to make the connection between the two even closer than they already were' (Ranke 2013 [1833]).

The Counter-Reformation in Italy brought economic development northwards. As the pillaging of Rome (1527) and the Counter-Reformation extinguished the developmental furore in Italy, the ideas had already moved north. As in Italy so in Germany learned societies sprang up, such as the Donaugesellschaft (Danubiana) in Austria and the Rheinische Gesellschaft (Rhenana) in Germany around 1500. It is important to keep in mind that the 1400 s and 1500 s were a very cosmopolitan age in Europe, with more foreign students at the main universities, percentagewise, than today. The cosmopolitan nature of the Catholic Church hierarchy also added to mobility and to the transportation of ideas. Giovanni Botero (1544-1617), the early social scientist, to whom I shall return, was born in Piedmont in Italy, but had his first books published in Krakow in Poland and Würzburg and Nürnberg in Germany. But these were also the times of early nationalism.

In Germany the duty-based system that I have described above - the permission to invent that was converted into a duty to invent - took on a particular political flavour. The rulers' divine right to rule became their divine duty to develop the state they ruled. In Germany this becomes very clear with Veit Ludwig von Seckendorff (1626-1692) and his Teutsche Fürstenstaat, first published in 1656. Seckendorff adds a strong dose of duty to the right of the ruler: 'Right becomes Duty, the lord of the land becomes the first servant of the state' (Lüdtke 1939, 67). The context of Seckendorff's writings is significant. He was of the generation born during the Thirty Years War (1618-1648), which devastated large parts of Germany. In some areas up to 70 per cent of the civilian population perished, and there was a feeling that a huge effort was needed - among other things, stopping religious wars - in order to save civilization itself. Philip von Hörnigk (1638-1712), to whom we shall return in Reinert and Rössner's Chapter 3 in this volume, wrote his bestselling book on Austrian economic policy during the years when the Turks were besieging Vienna. This book remained in print continuously for 100 years from 1684

22 This is recently discussed in Sebregondi and Parks (2011). 


\section{Handbook of alternative theories of economic development}

to 1784 , passing through 18 editions. The external and internal pressures helped to forge the new thinking, inspired from the South, in Northern Europe.

Being a 'Philosopher-King' became the prestigious goal of Northern European royalty (Wolff 1750). The connection to the prestige attached to the Byzantine philosophers at the Italian courts a century or two earlier is easy to see. Knowledge provided the King with prestige, and making the subordinates wealthy and knowledgeable added to this prestige. To this was added an admiration of the Chinese, their inventions and their high population density. Being able to feed a large population was an obvious sign of both economic success and good rule. Thus Mankind's energies could be channelled from warfare into something more constructive: building the nation. ${ }^{23}$ However, the competitive elements remained between the states, but no longer just in warfare. This diversity of states competing on different levels has been used as an argument to explain why Europe overtook China, which was ahead in terms of inventions and government not too long before (Reinert and $\mathrm{Xu}$ 2013).

This was the starting point of what Albert Hirschman has called 'a multi-level conspiracy for development'. Wilhelm Roscher, the German economist of the Historical School, was to call this type of government 'enlightened despotism' (Roscher 1868, 76-106). It is interesting to observe how the economists at the time encouraged, flattered and cajoled their rulers into adopting the right kind of economic policy. Many of them were at the same time researchers in the most diverse subjects, teachers, government advisors, business entrepreneurs on behalf of the state and the rulers, and a one-man research council (Reinert 2009).

\section{FROM EXPLORATIONS, TERRESTRIAL AND CELESTIAL, TO INNOVATIONS}

From the advent of clocks that gave time its metric measurability and inevitability, through the astronomers who shattered Man's mental prison, to the sailors who domesticated the oceans and seaways, the period around the turn of the sixteenth century is remarkable in the synergy we can observe between innovations and explorations, between men of theory and men of practice, in reshaping the European worldview. Men of theory and practice joined forces to weave a new European cosmology. The Late Renaissance historian William J. Bouwsma explored what he named the 'liberation' of a number of key concepts around the turn of the sixteenth century (Bouwsma 2000). As the static medieval worldview digested the process of new scientific breakthroughs, of geographical and scientific exploration, it was forced to broaden its horizons and accept, perhaps more than adopt, a more dynamic mentality. I would argue, on the basis of my previous qualifications, that the emancipation of two of Bouwsma's axioms - time and space fertilized the European worldview, making innovations acceptable and liberating growth and economic progress in theory as well as practice.

Something was slowly changed around the turning of the sixteenth century. Giovanni Botero and Antonio Serra - the economists of this account - testify to the gradual

23 This is the core of Hirschman (1977). 
nature of the epistemic shift. Worldviews do not change overnight, but rather cumulatively evolve on a level of time at once dependent on and detached from that of the 'event' (Braudel 1982, 26-52; Kuhn 1970, 151). Giovanni Botero (1544-1617) wrote two immensely influential books: The Causes of the Greatnesse of Cities (Botero 1589, first published 1588) a book on economics and statecraft, and Relazioni Universali (Botero 1599, first published 1591), a book on world geography, ethnography and explorations. Botero's works were indeed a strong indicator of changing times, but alone he was, of course, not enough to trigger the drastic change that took place. ${ }^{24}$

Botero (1589) warns, in a chapter on how to acquire the wealth of others, that 'to attract to oneself and acquire just possession of what belongs to another requires no less skill and judgment than to propagate what is one's own' (Botero 1589, 157). One could, in Botero's model of the economy, produce and propagate wealth, and the Prometheus of economic growth was thus unbound from his scholastic shackles. By removing the limits of growth, as well as some of its more restrictive moral barriers, Botero effectively expanded the limits of human endeavour, fusing a Heraclitean cosmology with economics (Sombart 1929; Popper 1957, 112-113). The economy went from static to dynamic, from a zero-sum game to a dynamic positive-sum game. The difference between the static and dynamic conceptions of reality can be traced back to Ancient Greece: Scholastic and modern mainstream economists follow Zeno's belief in a reality at once static and dynamic, whereas mercantilists and modern evolutionists adhere to the qualitatively changing world of Heraclitus. Karl Popper points out the semantic paradox resulting from this dichotomy: "For the kind of society which the sociologists call "static" is precisely analogous to those physical systems which the physicists would call "dynamic" (although stationary)' (Popper 1957, 112-113).

Newtonian physics would consider the solar system 'dynamic', insofar as it contains motion and change; whereas social scientists would call it 'static' since, apart from rare celestial phenomena that also can be explained within the framework of the model, it never undergoes structural change. There is no 'novelty', no 'innovation'.

Botero's insight was to translate into economic terms Giordano Bruno's (1548-1600) 1584 De l'infinito universo e mondi, a text considered heretical by ecclesiastical authorities that contributed considerably to the eventual calling of an auto-da-fé against him. Bruno reinterpreted the ideas of Lucretius' (c.99-55 BC) De rerum natura in the terms of Nicolas of Cusa (1401-1464) and Copernicus (1473-1543) (Koyré 1957, 18, 25, passim).

\section{ECONOMIC DEVELOPMENT AND RELIGION: A NOTE ON MAX WEBER AND HIS DISCONTENTS}

As explained, the system we call capitalism - which formed the foundation of modern economic development - took shape in competing Italian city-states from the twelfth century onwards. There were several contenders. Siena, artistically represented by Ambrogio Lorenzelli's mural Good and Bad Government from 1338-1339, had a head start. Genova played an important role in the early development of banking. So did Venice, which

24 For a further discussion of Botero's works see Reinert and Carpenter (2016). 
also pioneered a republican form of government which was to last for more than a millennium (from around AD 800). The early capitalist system probably reached its zenith during the Florentine Renaissance of the 1400s. At the time in Florence a small group of individuals left their intellectual footprint on history: universal genius Leonardo da Vinci (1452-1519), painter and sculptor Michelangelo Buonaroti (1475-1564), painter Sandro Botticelli (c.1445-1510) and Filippo Brunelleschi (1377-1464), the architect of the cathedral in Florence. Indeed this magna facere, doing great and beautiful things, came to be a key feature of the Renaissance: what great rulers, such as Lorenzo il Magnifico of Florence (1449-1492), promoted. Luca Pacioli (c.1447-1517), a collaborator of Leonardo, perfected the system of double-entry bookkeeping which made it possible for capitalists to determine how much capital they actually had.

How does this flair for greatness fit Max Weber's Protestant Ethic and the Spirit of Capitalism (1904/1905, 1920), a book 'in which he proposed that ascetic Protestantism was one of the major "elective affinities" associated with the rise in the Western world of market-driven capitalism and the rational-legal nation-state' (which is Wikipedia's oneliner on Weber's book)? Furthermore, how could the birth of capitalism start around 1200, while Protestantism, in the form of Lutheranism (Martin Luther, 1483-1436) and of Calvinism (Jean Calvin, 1509-1564), was born centuries later? Weber's story of Protestantism being at the root of capitalism has become a dominant narrative in its field in a similar way that Adam Smith has in the broader field of economics. I find it useful to bring back other perspectives.

In fact Weber's thesis was the product of an intense rivalry between two young German social scientists, one a year older than the other, whose fathers (Anton Sombart, 18161868, and Max Weber senior, 1836-1897) were both members of the German Parliament for the National-Liberal Party: Werner Sombart (1863-1941) and Max Weber (1864 1920). The fact that this was a fight apparently won by Weber does not mean that some of Sombart's points as regards economics and religion do not merit being brought back into the discussion. One reason is that Sombart's explanation of the origin of the system solves the problem of capitalism being born centuries before Protestantism.

Capitalism, as it came to develop, contains both ascetic values and conspicuous spending, personal spending on luxuries and state spending on wars. Thrift and parsimony without accompanying spending would have choked capitalism in underconsumption. In a 1957 book (Samuelsson 1964 [1957], 63-64) Swedish economic historian Kurt Samuelsson (1921-2005) makes a strong case against Weber's thesis, arguing - with Werner Sombart - that values that Weber sees as appearing only with Protestantism and Puritanism, with Benjamin Franklin, were in fact present already during the Renaissance:

As a debating point against Weber, Sombart drew attention in Der Bourgeois to the Renaissance writer Leon Battista Alberti, who in 1450 discussed the principles of 'holy housekeeping,' in a work whose general approach to diligence and thrift as economic virtues and to the 'rationalization' of human activity as a whole would have given Franklin himself no ground for objection.

Weber took up Sombart's criticism on this point in a note four pages long. He hunts zealously for points of difference between Franklin and Alberti. Minor variations of phraseology, such as the fact that Alberti speaks of the management of wealth while Franklin refers to the employment of capital, are inflated to major importance even though two different languages and a time-gap of 300 years are involved. (Samuelsson 1964 [1957], 63-64) 
The debate between the two young German academics on the role of religion in capitalism decayed into a decidedly unproductive quarrel. 'Weber's retaliatory note abounds with sophistries, distortions and circular arguments', Samuelson concludes.

Kurt Samuelsson uses the Dutch Republic, Europe's richest nation during its Golden Age - roughly spanning the seventeenth century - to show how successful capitalists there could be Catholics as well as Protestants. Indeed the Dutch Republic in this period seems to show both that thrift and luxury, for example in art, went hand in hand, and that (as previously referred) economic growth and development appear to increase when religious fervour - regardless of religion - diminishes.

\section{GIOVANNI BOTERO}

It is probably fair to say that early economic theory grew out of two much older and overlapping traditions:

1. The tradition of Xenophon's Poroi, a literary tradition later generally labelled Hausväterliteratur (it tends to be discussed in the German language), giving advice on how to run estates, small and large. ${ }^{25}$ The Fürstenspiegel ('Kings' Mirror') literature, bringing advice to the rulers on how to govern, can be seen as part of this broader tradition. The Sachsenspiegel, from German Saxony, about 1230, is the best known, but even in peripheral Norway, this tradition goes back to a text from around 1250: Konungs skuggsjá (Old Norse for 'King's mirror').

2. The tradition of accurate country surveys and descriptions, dating back to De magnalibus urbis mediolani of Bonvesin de la Riva (1288) and later works also on the Florentine state. Such descriptive surveys were the purpose of costly and extensive visitas in the Spanish provinces of the New World, some of which have been republished (Ortiz de Zúñiga, Iñigo 1967/1972).

Two apparently different economic traditions - cameralism and mercantilism - seem to have grown out of the extremely widely diffused works of Giovanni Botero (1544-1617) (Firpo 1971; Descendre 2009) as a common platform and point of reference. Botero's work Ragion di Stato (Firpo 1975, 139-164) satisfied the Fürstenspiegel tradition, while his Relazioni Universali (1591) satisfied the need for surveys and the fact-finding missions' quest for geographical, cultural and anthropological knowledge. All in all, at the time when the knowledge of the whole world and its cultures became codifiable, Giovanno Botero provided an unusually complete range of social sciences. It is worth noting that in contrast to the many utopias of the period, Botero's reasoning was based on the observation of history and of facts. ${ }^{26} \mathrm{In}$ his work he clearly distances himself from

25 On the Hausväterliteratur as an alternative type of economic theory, originating on the European continent, see the interesting discussion in Burkhardt and Priddat (2000).

${ }_{26}$ Of course Botero made mistakes, such as when his sources were not correct. The remarkable thing, however, is the acuteness of his analysis of generalized wealth and policy prescriptions that came to typify the centuries of economics that go under the name of cameralism and mercantilism. Botero was involved in the process of making the Vatican's list of prohibited books, which in Botero's days also comprised the works of Jean Bodin (1530-1596). This position clearly gave him access to much new material. 
'bullionism' - the idea that a nation's wealth consists in the amount of precious metals owned - of which mercantilism is sometimes accused.

Botero was born in the small town of Bene Vagienna in the province of Cuneo in the Italian Piedmont region. As a Jesuit, he was keenly interested in non-European cultures. ${ }^{27}$ From the point of view of now long-standing Western Eurocentrism, the ability of the Jesuits to engage in two-way cultural communication reminds us that Eurocentrism is not necessarily a 'natural' state of affairs. Jesuit Matteo Ricci (1552-1610), a contemporary of Botero, ventured with a small group to China, where he translated not only Christian and Western scientific texts into Chinese, but also Chinese texts into Latin (Spence 1983). By entering inside foreign cultures - from the Chinese to the Guaraní in South America - Jesuit travellers also played the role of anthropologists. As one observer says, Botero 'brought together an immense mass of geographical and anthropological information, which he tried to organize according to broad methodological categories (like "resources", "government", and "religion")' (Rubies 2000, 294).

Apparently little unites Sir Walter Raleigh (1554-1618), utopian Tommaso Campanella (1568-1639), English economist Edward Misselden (1608-1654), Spanish economist Gerónimo de Uztáriz (1670-1732), and Swedish technologist and economist Christopher Polhem (1661-1751). But one thing does: they all convey key insights found originally in Giovanni Botero, but following the practice of the time they do not quote him or anyone else as to the origins of these insights. Clearly the work of the first German bestseller, Veit von Seckendorff (1626-1692) is also very much influenced by Botero (E. Reinert 2005). There are still 30 editions of Botero's works (mainly uncatalogued) in the Gotha Library that Seckendorff formed for Ernest the Pious (Ernst der Fromme) of Sachsen-GothaAltenburg, and Botero was on the reading list Seckendorff made for the education of princes (S. Reinert 2005). The large number of translations of Botero's works testifies to his strong influence on the European seventeenth century zeitgeist (see Tables 1.1 and 1.2 for a list of editions).

Botero's small book ( $3+79$ pp) The Cause of the Greatnesse of Cities / Sulla Grandezza delle Città (first edition 1588) was the first economic bestseller, reaching a record 40 editions before $1850,{ }^{28} 38$ of them between 1588 and 1671 . Only one year later, this volume was included in the much larger work Ragion di Stato $(8+368 \mathrm{pp})$ which in English came to be called Reason of State and in German Staatsräson. In his 1925 work on Staatsräson Meinecke mentions Botero's many followers and the 'true catacombs of forgotten literature' which follow in Botero's path. ${ }^{29}$ In Tables 1.1 and 1.2 it is not yet completely clear which editions of Ragion di Stato contained Greatnesse of Cities and which did not. There is a new translation of Botero's The Cause of the Greatnesse of Cities with an excellent introduction by Geoffrey Symcox (Botero 2012; Symcox 2012).

The understanding that grew out of Botero's work was that only in barren areas lacking natural resources and with limited possibilities for food production - but in favourable geographical positions such as Venice and in the Dutch Republic - would

\footnotetext{
27 '[T]he very purpose of the group Loyola gathered during his studies in Paris was the apostolate with the Muslims in the Holy Land' (Maryks 2008).

28 The reference to 1850 in terms of book publications in this chapter is the result of the author's work on documenting economic books published before that date.

29 'Wahre Katakomben von vergessener Literatur' (Meinecke 1925, 83n).
} 
Table 1.1 Giovanni Botero: Cause della Grandezza delle Città / Della Ragion di Stato, editions before 1850

\begin{tabular}{|c|c|c|}
\hline & Place & Date \\
\hline 1. & Rome & 1588 (only Grandezza) \\
\hline 2. & Rome & 1588 (only Grandezza + historical piece on Rome) \\
\hline 3. & Venice & $\begin{array}{l}1589 \text { (1st edition of Ragion di Stato, also including } \\
\text { Grandezza) }\end{array}$ \\
\hline 4. & Ferrara & $\begin{array}{l}1589 \text { (hereafter, both works are included unless otherwise } \\
\text { indicated) }\end{array}$ \\
\hline 5. & Rome & 1590 \\
\hline 6. & Madrid & 1593 (Spanish) \\
\hline 7. & Milan & 1596 (only Grandezza, publisher Pacifico Ponzio) \\
\hline 8. & Milan & 1596 (only Grandezza, publisher S. Barberino) \\
\hline 9. & Turin & 1596 \\
\hline 10. & Milan & 1596 \\
\hline 11. & Milan & 1597-98 (Ragione 1597, Cause 1598) \\
\hline 12. & Venice & 1598 \\
\hline 13. & Pavia & 1598 (without Cause) \\
\hline 14. & Venice & 1598 (without Cause) \\
\hline 15. & Paris & 1599 (French, without Cause) \\
\hline 16. & Barcelona & 1599 (Spanish, without Cause) \\
\hline 17. & Venice & 1601 \\
\hline 18. & Ursellis/Oberursel & 1602 (Latin) \\
\hline 19. & Strasbourg & 1602 (Latin) \\
\hline 20. & Burgos & 1602 (Spanish, without Cause) \\
\hline 21. & Burgos & 1603 (Spanish, without Cause) \\
\hline 22. & Barcelona & $1605($ Italian + Relazioni $)$ \\
\hline 23. & London & 1606 (English, only Grandezza) \\
\hline 24. & Burgos & 1606 (Spanish, without Cause) \\
\hline 25. & Turin & 160626. \\
\hline 26 & Paris & 1606 (French, Maximes d'estat militaires et politiques. . .) \\
\hline 27. & Venice & 1606 \\
\hline 28. & Venice & $1608(+$ Relazioni $)$ \\
\hline 29. & Milan & 1609 \\
\hline 30 . & Bologna & 1609 \\
\hline 31. & Turin & 1610 \\
\hline 32. & Cologne & 1613 (Latin) \\
\hline 33. & Cologne & 1615 (Latin) \\
\hline 34. & Venice & 1619 \\
\hline 35 . & Venice & 1619 \\
\hline 36. & London & 1635 (English, only Grandezza) \\
\hline 37. & Venice & $1640(+$ Relazioni $)$ \\
\hline 38. & Frankfurt & 1657 (German) \\
\hline 39. & Venice & $1659(+$ Relazioni $)$ \\
\hline 40. & Venice & 1659 \\
\hline 41. & Frankfurt & 1661 (1664?) (German) \\
\hline 42. & Helmstedt, Germany & 1666 (Latin) \\
\hline 43. & Venice & $1671(+$ Relazioni $)$ \\
\hline 44. & Milan & 1830 \\
\hline 45. & Milan & 1839 \\
\hline
\end{tabular}


18 Handbook of alternative theories of economic development

Table 1.2 Giovanni Botero: Relazioni Universali, editions before 1850

\begin{tabular}{|c|c|c|}
\hline & Place & Date \\
\hline 1. & Rome & 1591 \\
\hline 2. & Rome & $1592-93$ \\
\hline 3. & Ferrara & 1592 \\
\hline 4. & Bergamo & $1594-96$ \\
\hline 5. & Rome & 1595 \\
\hline 6. & Rome & 1595 \\
\hline 7. & Venice & 1595 \\
\hline 8. & Vicenza & 1595 publisher G. Greco \\
\hline 9. & Vicenza & 1595 publisher Eredi di Perin libraio \\
\hline 10. & Brescia & $1595-96$ \\
\hline 11. & Rome & 1596 \\
\hline 12. & Bergamo & 1596 \\
\hline 13. & Venice & 1596 publisher G. Vincenti \\
\hline 14. & Venice & 1596 publisher G.B. Vssio \\
\hline 15. & Venice & 1596 publisher G. Angelieri \\
\hline 16. & Bergamo & 1596 \\
\hline 17. & Venice & 1596 \\
\hline 18. & Cologne & 1596 German, publisher J. Gymnici Erben \\
\hline 19. & Cologne & 1596 Latin, publisher C. Andree \\
\hline 20. & $\begin{array}{l}\text { Manuscript in British Museum, } \\
\text { London }\end{array}$ & 1596 German \\
\hline 21. & Venice & 1597 \\
\hline 22. & Vicenza & 1597 \\
\hline 23. & Rome & 1597 \\
\hline 24. & Venice & 1597 \\
\hline 25. & Frankfurt & 1598 Latin \\
\hline 26. & Brescia & 1598 \\
\hline 27. & Venice & 1598 \\
\hline 28. & Cologne & 1598 Latin \\
\hline 29. & Brescia & 1599 \\
\hline 30. & Venice & 1599 \\
\hline 31. & Venice & 1599 \\
\hline 32. & Cologne & 1599 German \\
\hline 33. & Valladolid & 1599 Spanish \\
\hline 34. & Venice & 1600 \\
\hline 35. & Lübeck & 1600 Latin \\
\hline 36. & Turin & 1601 \\
\hline 37. & London & 1601 English \\
\hline 38. & Venice & 1602 \\
\hline 39. & Ursellis/Oberursel & 1602 German \\
\hline 40. & Ursellis/Oberursel & 1603 Latin \\
\hline 41. & Barcelona & 1603 Spanish \\
\hline 42. & Venice & 1605 \\
\hline 43. & Barcelona & 1605 Spanish \\
\hline 44. & Turin & 1607 \\
\hline 45. & Venice & 1608 publisher A. Angelieri \\
\hline
\end{tabular}


Table 1.2 (continued)

\begin{tabular}{|c|c|c|}
\hline & Place & Date \\
\hline 46. & Venice & 1608 publisher G. Bertano \\
\hline 47. & Barcelona & 1608 Spanish \\
\hline 48. & Valladolid & 1609 Spanish \\
\hline 49. & London & 1611 English \\
\hline 50. & Venice & 1611 \\
\hline 51. & Munich & 1611 German \\
\hline 52. & Munich & 1611 German \\
\hline 53. & Venice & 1612 \\
\hline 54. & Cologne & 1613 Latin \\
\hline 55. & Krakow & 1613 Polish \\
\hline 56. & Frankfurt & 1614 Latin \\
\hline 57. & Venice & 1618 \\
\hline 58. & Marburg & 1620 Latin \\
\hline 59. & Helmstedt & 1620 Latin \\
\hline 60. & Gerona & 1622 Spanish \\
\hline 61. & Venice & 1622 \\
\hline 62. & Leyden & 1625 Latin \\
\hline 63. & Leyden & 1626 Latin \\
\hline 64. & Leyden & 1627 Latin \\
\hline 65. & Leyden & 1629 Latin \\
\hline 66. & London & 1630 English \\
\hline 67. & Leyden & 1633 Latin \\
\hline 68. & Venice & 1640 \\
\hline 69. & Venice & 1640 \\
\hline 70. & Leyden & 1642 Latin \\
\hline 71. & Leyden & 1642 Latin \\
\hline 72. & Leyden & 1647 Latin \\
\hline 73. & Jena & 1648 Latin, translated from German \\
\hline 74. & Venice & 1650 \\
\hline 75. & Venice & 1659 \\
\hline 76. & Venice & 1662 \\
\hline 77. & Helmstedt & 1664 Latin \\
\hline 78. & Leipzig & 1667 Latin \\
\hline 79. & Bologna & 1668 \\
\hline & Helmstedt & 1670 Latin \\
\hline & Venice & 1671 \\
\hline & Gerona & 1748 Spanish \\
\hline & Venice & 1795 \\
\hline 84. & Venice & 1796 \\
\hline
\end{tabular}

Note: Not all editions are complete. Except for corrections in chronology, I have followed the entries by Assandra (1926/1928). In contrast to Botero's Grandezze, this book was prohibited in France, which explains the lack of French translations. Publishers are indicated only when the editions of the same year in the same city were by different publishers. 


\section{Handbook of alternative theories of economic development}

economic development tend to come 'naturally'. In virtually all countries heavy-handed government policies were required during the transition from diminishing returns activities (agriculture) to increasing returns activities (manufacturing), as they were identified by Serra (1613); or from 'natural activities' to 'artificial activities', using the terminology of Thomas Mun (1664). This was the essence of the thinking that Botero's influence turned into the economic mainstream at the time. What Venice and the Dutch Republic rather than the policies of Venice and the Dutch Republic - had achieved was the object of attention of foreign economists and foreign rulers alike.

The theoretical conflict between the forefathers of today's mainstream canon and what we could call the Renaissance canon has existed at least since the 1622-1623 'English' debate between Gerard de Malynes (Malynes 1622, 1623) and Edward Misselden (Misselden 1622, 1623), where Malynes represented a static theory rooted in barter and Misselden represented a theory centred around learning and production. In the history of economic thought, their debate is interpreted as being about exchange controls and the balance of trade. ${ }^{30}$ The controversy between the two was an 'acrimonious, even abusive' one, in which 'ink was shed like water' (Buck 1942, 23).

However, by going back to the sources, one finds that the main line of attack by Misselden against Malynes is his 'mechanical' view of Man: Malynes has left out Man's 'art' and 'soul'. Misselden quotes at length a paragraph from Malynes, where Malynes reduces trade to three elements, 'namely, Commodities, Money, and Exchange' (Misselden 1623, 8). Objecting to this definition, Misselden says: 'It is against Art to dispute with a man that denyeth the Principles of Art'. Misselden scorns Malynes for not seeing the difference between a heap of stones and logs and a house; because Man's productive powers and his soul, which produce the house, have been left out. Typically, the wealth of a nation was seen as lying in its capacity to produce, its 'productive powers' as Friedrich List put it.

The importance of the difference between heaps of stones and logs and a house rings a bell when reading Botero, the first English translation of which was in 1605:

some will aske me; whether Fertilitie of Land, or Industrie of Man, importeth more to make a place Great, or populous? Industrie, assuredly. First because Manufactures framed by the skilfull hand of Man, are more in number, ${ }^{31}$ and price, ${ }^{32}$ than things produced by Nature: For Nature giveth matter, and subject: but the Curiositie and Art of Man addeth unspeakable varietie of formes. Wool, from Nature, is a rude and simple Commoditie: What fair things, how various, and infinite, doth Art make out of it? ${ }^{33}$

Compare the Marbles, with the Statues, Colossuses, Columns, Borders, and infinite other Labours, taken. Compare the Timber, with the Galleys, Galleons, Vessels of many sorts, both of Warre, Burthen, and Pleasure: Compare also the Timber, with the Statues, the Furnitures for Building, and other things innumerable, which are built with the Plane, Chesill, and TurnersWheele. Compare the Colours with the Pictures ... [etc.]. (Botero 1635, 88-89)

\footnotetext{
30 Schumpeter discusses the controversy between the two men (Schumpeter 1954, 344-345). See also their respective entries in The New Palgrave. In all cases these references are purely to the mechanics of money and exchange.

31 That is, greater diversity of products.

32 This could be interpreted as meaning more imperfect competition due to higher barriers to entry.

33 The second English translation is clearer on this and is used here (Botero 1635, 85-86).
} 
Botero's distinction between raw materials and the finished goods which are created by the arts certainly recalls Thorstein Veblen's insistence on the instinct of workmanship, rather than Adam Smith's barter instinct, as the origin of wealth. Misselden represents the acute Renaissance awareness of the vast territory to be covered between Mankind's present poverty and ignorance, and the enormous potential. Realizing this potential released enthusiasm and energy. The situation recalls Keynes's frustration with the suboptimal situation of the world under the Great Depression. Both the Renaissance philosophers and economists and Keynes were searching for the formula needed to liberate society from its obviously less than optimal position at the time. It recalls what Keynes called 'Salvation through Knowledge'. This attitude is very different from Man as the passive victim of 'two sovereign masters, pain and pleasure' (Bentham 1780, Ch. I, 11), which is the philosophical foundation of English classical economics and implicitly also of modern neoclassical economics.

In England, Sir Walter Raleigh was also studying Botero's treatise. His 'Observations Concerning the Causes of the Magnificency and Opulence of Cities' is a precis of Botero's text (Raleigh 1751, Vol. 2, 321-329). For example, Raleigh's final section, 'The Causes That Concern the Magnificency of a City', closely follows Botero's translation of the conclusion to Book III of 'On the Causes'. Raleigh's interest in 'On the Causes' seems to be linked to his colonial projects. Echoing Botero's conception of a civilizing process in which cities were instrumental (Book I, Ch. 2), Raleigh's opening statement alludes to the need to 'civilize and reform the savage and barbarous lives and corrupt manners of such People', presumably the American Indians. ${ }^{34}$ Recognizing the 'uncivilized' nature of most non-European cultures could lead to a desire to protect them, as in the policy of Botero and also the official policy of the Spanish monarchy towards the Indians. It could also lead to a desire to colonize and exploit them as cheap labour. It is also likely that William Petty (1623-1687), who entered a Jesuit college in Caen in France at the age of 14 , would have been exposed to Botero, whose ideas were very much in fashion at the time.

The Spanish mercantilist Geronimo de Uztáriz (1670-1732), whose main work was translated into both French and English, commented from a particularly good vantage point, being a Spaniard and having lived in Holland and Italy for 23 years. Uztáriz's conclusion reflects Botero's line on the role of manufactures and the sterility of gold per se: '[Manufactures] is a mine more fruitful of gain, riches, and plenty, than those of Potosí. ${ }^{35}$

The text below, from an economics student in Uppsala in 1747, sums up the mercantilist argument with emphasis on population density. We find the same much earlier argument in William Petty, who developed it into a policy recommendation: move the population from sparsely populated areas in the periphery of the realm to London, where they are more useful. This also reflects the policies of the Jesuits in Latin America, where the native populations were brought into city-like reducciones. The author, Gustav Westbeck, was a student of Anders Berch in Uppsala:

\footnotetext{
34 The discussion of Botero and Raleigh is based on Symcox in Botero (2012, xiv).

35 Potosí, at about 4000 metres above sea-level in present-day Bolivia, was the richest of all mines in the world. At the time, it was the probably the largest city in the Americas (with a population of around 150000 in the mid-1600s, it was about double the size of Lima).
} 


\section{Handbook of alternative theories of economic development}

How things really are in national economics, is nowhere clearer than in the case of the United Netherlands. They have virtually no domestic [resources], but still, through the industry of its large population, exceed in strength the immense but sparsely populated and idle Spain. [The Netherlands] knows well how to use the folly of others to its own benefit. We see how poor Spain is with all its gold and silver mines, the best ports and the best soil in the world, because of its lack of inhabitants. On the other hand how its large number of inhabitants make the United Provinces mighty, with their miserable ports and the worst climate on earth. (Westbeck $1747,4-5)$

The explosive spread of Botero's Grandezza delle Città is shown in Table 1.1. Counting Strasbourg - where Seckendoff had studied - as Germany, there were four editions of the work published in Germany before the start of the Thirty Years War. The others were one in Ursellis/Oberursel (near Frankfurt) and two in Cologne. All were in Latin. The first German translation appeared in Frankfurt in 1657. It is interesting to note how the editions grew fewer during the war, all over Europe, and how the frequency picked up again afterwards.

Table 1.1 includes all editions found so far of Cause della Grandezza delle Città (first edition Rome 1588), all editions of Della Ragion di Stato (first edition Venice 1589), and all editions of Relazioni Universali (first edition Rome 1591) when they are bound with Ragion di Stato.

Table 1.2 lists 83 independent editions of the Relazioni Universali between 1591 and 1796 (there were no editions between 1796 and 1850). The Relazioni Universali was published in Italian (from 1591), German (first two editions Cologne 1596), Latin (first two editions in Frankfurt and Cologne 1598), English (first in London 1601), Spanish (first in Valladolid 1599), and Polish (first in Krakow 1613). Botero's bibliographer Assandra (Assandra 1926, 407-442; 1928, 29-63, 307-351) informs us that the Relazioni was a prohibited book in France. In terms of the number of editions of his books, Botero comes out favourably compared to Adam Smith, whose 1776 Wealth of Nations - in an immensely more literate period than the 1600 s - reached 94 editions before 1850 (data from Bullock 1939).

\section{ANTONIO SERRA}

From what little we know of it, Antonio Serra's life comes across as a stark contrast to that of Giovanni Botero. ${ }^{36}$ We have no details of his date of birth or life, but we know from the title page of his book that Antonio Serra was born in Cosenza in Southern Italy. Cosenza is an old settlement dating back to Roman times, and was also the birthplace of the philosopher Bernardino Telesio (1509-1588), upon whom Francis Bacon bestowed the title 'the first of the moderns'. What else we know is that, while in a jail in Naples, Serra wrote a Brief Treatise, ${ }^{37}$ a book of such rarity that only about six copies are known to exist today, and that he died in jail a few years later. While Botero experienced fame and saw a large number of editions and translations appear during his lifetime, Serra

\footnotetext{
36 On Serra see also Patalano and S. Reinert (2016); some of the material in this section is from my chapter in this volume, E. Reinert (2016).

37 For the first English translation, see Serra (2011).
} 
died completely unrecognized under squalid conditions in a jail in Naples. He informed his readers that the next book he planned to write would bear the title On the Power of Ignorance, but he never wrote it.

Some 350 years later, however, Joseph Schumpeter gave Antonio Serra the honour of having been 'the first to compose a scientific treatise ... on economic principles and policy' (Schumpeter 1954, 195). Schumpeter's succinct description of Serra's work confirms the author's anti-bullionist bias, the normal criticism against mercantilists:

Its chief merit does not consist in his having explained the outflow of gold and silver from the Neapolitan Kingdom by the state of the balance of payments but in the fact that he did not stop there but went on to explain the latter by a general analysis of the conditions that determine the state of an economic organism. Essentially, the treatise is about the factors on which depend the abundance not of money but of commodities - natural resources, quality of the people, the development of industry and trade, the efficiency of government - the implication being that if the economic process as a whole functions properly, the monetary element will take care of itself and not require any specific therapy. ${ }^{38}$

Giovanni Botero and Antonio Serra represent the start of an economic tradition that became a key building block for the type of economic theory which built the Europe that soon would take over world economic leadership from China. ${ }^{39}$ The modern world as we know it, in short, emerged from the sort of economic ideas and policies Serra represented. His conscious focus on the real economy as opposed to the financial economy can be seen as a continuation of an anti-hoarding tradition that leads back to the Bible, but his emphasis on increasing returns and a large diversity of economic activities was entirely new.

Regardless whether this long theoretical tradition which dominated Europe until the late eighteenth century be labelled mercantilist, Colbertist or cameralist, Botero's narratives and Serra's theories in a sense laid the foundations for all three schools by establishing two crucial dichotomies in economics. The taxonomies Serra established are important for understanding the wealth and poverty of nations, and indeed provide a continuing key to what his contemporaries called buon governo, or 'good government'.

US historian Richard Goldthwaite shows the historical importance of the dichotomy between raw materials and manufacturing: what is generally seen as Europe's 'commercial revolution', Goldthwaite argues, was in fact a process of import substitution. Manufactured goods, that had previously been imported from the Levant, started to be produced in Europe itself from the twelfth century onwards (Goldthwaite 2009, 6-8). As is often observed, practice is born before theory.

Serra's two dichotomies, I will argue, were in the recent past still part and parcel of all three dominant ideologies and their economic policies in the $1930 \mathrm{~s},{ }^{40}$ but were subsequently lost with the formalization of modern neoclassical economics, and are conspicuously absent in the rather superficial discussion of good governance presented by the Washington institutions today.

The first is a dichotomy separating economic activities subject to increasing returns

38 Schumpeter $(1954,195)$. Note the term 'economic organism', which indicates a type of economic theory based on biological metaphors, rather than on metaphors from physics as is present-day theory.

39 For data see Bolt and van Zanden (2014, 627-651).

40 I am here referring to communism, fascism and Roosevelt's New Deal. 


\section{Handbook of alternative theories of economic development}

from those subject to diminishing returns. Putting 'manufacturing' in another category than 'raw materials' from the point of view of policy-making had already been the core element of the English Tudor strategy from 1485, promoting woollen manufactures at the expense of the export of raw wool by slowly building up the export duties of raw wool. ${ }^{41}$ There had been scattered references to the wisdom of such practices, ${ }^{42}$ but what Giovanni Botero did in his volumes was to elaborate the vision of the role of manufacturing, the insight that civilization was based on adding knowledge and value to Nature's raw material, into a full-fledged theory of economic development.

In Botero's volume the degree of economic and societal development manifested itself as the ability of a city to hold the maximum number of inhabitants in satisfactory conditions. This again was the result of the number of different professions that were exercised in the city: in other words, the degree of division of labour - the degree of complexity would determine the wealth of a city. ${ }^{43}$ Botero explained the mechanisms, but Serra's big contribution to this was to explain why. He did so by highlighting the key difference between the production of raw materials and manufactured goods, that is, what happens to the development of costs as production is increased. In manufacturing there were increasing returns, and the synergies of the multitude of artisanal and manufacturing activities, each of them subject to increasing returns, produced the linkages and cumulative causations that Botero and Serra saw as being the main factor which attracted so many people to the city-states that had specialized in manufacturing.

In the first edition of his Principles of Economics Alfred Marshall, the founder of neoclassical economics, emphasizes the crucial importance of diminishing returns: 'The tendency to a Diminishing Return was the cause of Abraham's parting from Lot, ${ }^{44}$ and of most of the migrations of which history tells' (Marshall 1890, 201). Today the migration experienced in Europe is from nations dominated by diminishing returns activities (for example, Eritrea) to nations where increasing returns activities dominate (for example, Holland).

The second dichotomy is that separating the financial sector from the real economy. As already mentioned, this dichotomy is of course much older than Serra's work. An academic expression of the problems which may arise when the financial and monetary spheres decouple hails back at least to Nicolaus Oresme (c.1320-1382) ${ }^{45}$ This dichotomy is not there in Botero's Greatness of Cities - which concentrates on the real economy - but it is very much there in Antonio Serra's discussion with his contemporary MarcAntonio de Santis on how to deal with the outflow of money from the Kingdom. ${ }^{46}$ De Santis was of the opinion that the lack of money in the Kingdom was due to the excessively high level of the exchange rate. On the basis of his theory several measures had been introduced to manage the rate of exchange and limit the export of metallic money, without positive results. Serra, on the other hand, starts by noting that there are countries with

\footnotetext{
41 For a thorough discussion see Reinert (2007).

42 Luis Ortiz's 1558 memorandum to King Philip II of Spain is a famous example.

43 This argument is being rediscovered; see Hausmann and Hidalgo (2014).

44 Marshall's footnote here: "The land was not able to bear them that they might dwell together; for their substance was great so that they could not dwell together". Genesis xiii. 6.'

45 Nicolas Oresme (1356), De Moneta. For a recent discussion see Schefold et al. (1995).

46 This was a problem of the whole of Spain, not only in the Spanish Viceroyalty of Naples where the discussions between Serra and de Santis took place.
} 
no natural supplies of metals from domestic mines that nevertheless manage to have an abundance of money. In other words, Serra asks: why on earth do the gold and silver which flow into Spain from the New World end up accumulating in places like Venice, which have no mines and raw materials at all?

Serra's reply was based on Botero's analysis of what attracted people and resources to some cities and not to others, above all the abundance of different manufacturing industries. In other words the solution to the problems posed by dichotomy two - the conflict between the financial and the real economy - lies in observing the insights emanating from dichotomy one: money will leave the cities and countries with no increasing returns activities, being attracted to cities with manufacturing and increasing returns. In Schumpeter's quote above he emphasizes Serra putting the real economy at centre stage: 'if the economic process as a whole functions properly, the monetary element will take care of itself and not require any specific therapy' (Schumpeter 1954, 195).

In fact, digging deeper into Serra's arguments, we can argue with him that de Santis's fiddling with monetary variables - as long as these monetary variables did not positively affect the health of the real economy - were not only completely in vain, but potentially destructive to the real economy. The present tragedy of Greece inside the European Union carries with it the same type of discussion as that between Messrs de Santis and Serra more than 400 years ago.

The jury is still out on whether the policies carried out from the start of the financial crisis until the present (2016) by the Federal Reserve - and even more so those of Mario Draghi and the European Central Bank - again will justify Antonio Serra's warning: fiddling around with financial variables, which in reality do not improve conditions in the real economy, will not help, but will probably worsen the situation. Schumpeter saw the need for economic 'cold showers' provided by financial crises, because unproductive capital lost its value and the system was reset with a clean slate. From that point of view we can ask whether Draghi, by providing more liquidity and more debt, presently prevents Europe from taking the necessary 'shower', cleansing itself from a huge debt overhang and kick-starting the real economy. Increasing debt and demand contraction in vicious circles - as a result of policies of austerity - seem to prevent the virtuous circles that originate in Serra's increasing returns to scale (that is, falling unit costs as the volume of production increases).

I shall also briefly discuss how Serra's distinction between increasing and diminishing returns is crucial to an understanding of technology optimism and technology pessimism, looking at the situations where 'limits to growth' may be converted into 'green sustainability'. Based on Serra's insights about increasing returns it is perfectly possible to have intensive growth, that is, growth in incomes without a corresponding growth in resource throughput. This is what is meant, in fact, by increasing returns: getting more out of what is put in. So capturing increasing returns means, essentially, embarking on a process of intensive growth, which, if based on renewable energies and resource recirculation, can accurately be called 'green growth'. Employing Serra's theory today, in the energy sector green growth would mean going from a system of extracting fossil fuel to a system of harvesting nature's energy. ${ }^{47}$

47 This possibility, outlined in Mathews and Reinert (2014) will be discussed later in this chapter. 


\section{Serra's Key Dichotomy: Increasing versus Diminishing Returns and its Crucial Importance as the Determining Factor of Wealth and Poverty}

As my son Sophus A. Reinert has argued (in Serra 2011), Antonio Serra's treatise could be read as an extended meditation on one of Giovanni Botero's most crucial passages. In his Ragion di stato, Botero wrote:

such is the power of industry that no mine of silver or gold in New Spain or Peru can compare with it, and the duties from the merchandise of Milan are worth more to the Catholic King than the mines of Potosi and Jalisco. Italy is a country in which . . there is no important gold or silver mine, and so is France: yet both countries are rich in money and treasure thanks to industry. ${ }^{48}$

Throughout his work Botero argues for the superiority of industry in terms of what we would call synergies from a diversity of economic activities, in terms of the greater possibility of innovation in city activities, and in terms of their ability to yield a larger profit than countryside activities. His observations were certainly shared by any experienced traveller in Europe at the time, but Botero fails to provide a convincing theoretical argument for why this is so. What are the qualitative differences between city activities and countryside activities? Explaining this is Antonio Serra's greatest contribution to economics, and one of the reasons Joseph Schumpeter argued that his work amounted to the earliest scientific treatise on economic principles and policy (Schumpeter 1954, 194-195).

Serra wrote in Naples, a poor city with a lack of food and occasional food riots; a particularly violent one had taken place in $1585 .{ }^{49}$ He followed Botero's lead in differentiating work in the agricultural and manufacturing sectors, but qualified the distinction further by grounding it in the theories of increasing and diminishing returns to scale whether unit production costs would rise or fall if a nation chose to specialize in any particular activity - to produce the first coherent statement of this important economic law (De Luca 1968, 33). Manufactures, Serra argued, are unique because the costs of labour proportionally go down with increasing volumes of production:

There can be multiplications in manufactures which lead to a multiplication of profits, something which does not happen in agriculture as one cannot multiply it. Nobody, for example, having a territory upon which only a hundred tomola of wheat can be sown, will be able to have a hundred and fifty sown; but among the manufactures, it is just the other way, since they may be multiplied not only two-fold but two hundred-fold, and with proportionately less expense. ${ }^{50}$

\footnotetext{
48 (Botero 1589, 152). Following Botero the use of the Potosí mines to highlight the importance of manufactures becomes a leitmotif in early modern political economy across Europe. For example, we find Geronimo de Uztáriz in 1751 proclaiming '[Manufactures] is a mine more fruitful of gain, riches, and plenty, than those of Potosí' (Uztáriz 1751, Vol. 1, 9). The first professor of economics outside Germany, Anders Berch in Uppsala, compares manufacturing to 'inexhaustible gold mines' (Berch 1747, 216). The term used is outlöselige Guldgrufwor.

49 Selwyn (2004). See page 73 for the 1585 bread riot.

50 Serra, Antonio, Breve trattato (Brief Treatise) (1613), pp. 11-12: 'nell'artefici vi può essere moltiplicatione, e per quella moltiplicarsi il guadagno, lo che non può succedere nella robba, non si possendo quella multiplicare, che nissuno (per essempio) se in alcuin suo territorio non si può seminare se non cento tomola di frumento, potrà fare che se ne semino centocinquanta, ma nell'artificii è il contrario, che si possano moltiplicare non solo al doppio, ma a cento doppi e con minor proportione di spesa'.
} 
Increasing and diminishing returns - more often separately than together - have played an important role in the history of economic thought. As already mentioned, Serra was no doubt the first to explain these mechanisms, and in this way added the theoretical mechanisms behind Botero's astute observations and explanations. Examining Serra's argument more closely, it is essentially one which explains the difference in purchasing power in manufacturing in competition with other nations, as well as one about how manufacturing and increasing returns create barriers to entry and imperfect competition on a company level.

Today increasing returns are important in industrial economics as a main source of barriers to entry (Tirole 1982, 305). In his classical work on the subject, Joe Bain defined as a barrier to entry anything that allows incumbent firms to earn supernormal profits without threat of entry (Bain 1956). Our claim is that there is a direct link between the imperfect competition found in manufacturing - allowing higher profits and higher wages and thus making it profitable to invest in labour-saving technological innovations - and economic growth and development. A key link in this process is the steadily increasing demand that comes as a by-product of this process. Any businessman knows that 'perfect competition' is tantamount to not making money, and would see the idea of 'not making money' - that is, perfect competition - as a strange concept to be put at the core of capitalist economic theory, as is done in neoclassical eonomics. Figures 1.1 and 1.2, based on Serra's theories, describe the virtuous and vicious circles of economic development. ${ }^{51}$

If we ask ourselves why Bill Gates makes more money than a Seattle housepainter, the differences in scale effects, and consequently in barriers to entry, are an important part of the explanation. The house painter in practice operates under constant returns to scale: after having painted one house, the time and material employed to paint a second identical house will be the same as with the first house. In Bill Gates's Microsoft it may take an investment of $\$ 500$ million to develop a new generation of programs - in other words unit number one produced costs $\$ 500$ million - but subsequent units produced will cost only fractions of a dollar to distribute electronically. In this way Gates's profits, as opposed to that of the house painter, are protected by the high fixed costs of producing unit number one. The lowering of cost of producing additional units, extreme in the case of Gates, is what is found at differing degrees in manufacturing, but - as Serra concluded above - this is not found in agriculture. This is because in agriculture (and mining) one factor of production (land, ore) comes in different qualities, limited by Nature. Serra was the first to describe increasing and diminishing returns, the virtuous circles of cumulative causations where - protected from perfect competition - the dynamic increasing returns of manufacturing allow profits, wages and tax income to create what we call economic development. It is important to note that while traditionally increasing returns have been limited to manufacturing, they are also now increasingly found in the advanced service

51 My PhD thesis in economics (Reinert 1980) was an empirical test of Serra's theory: to what extent was manufacturing production subject to increasing returns and the production of raw materials subject to diminishing returns? The answers overwhelmingly proved the validity of Serra's theories: the main export items of Bolivia, Ecuador and Peru showed huge diminishing returns, which could most easily be seen as huge increases in labour productivity any time production was sharply reduced (as in the 1930s). This result would not surprise any agricultural or mining economist, but the practical importance of this for economic development and its absence has long been neglected in the realm of economic policy. 


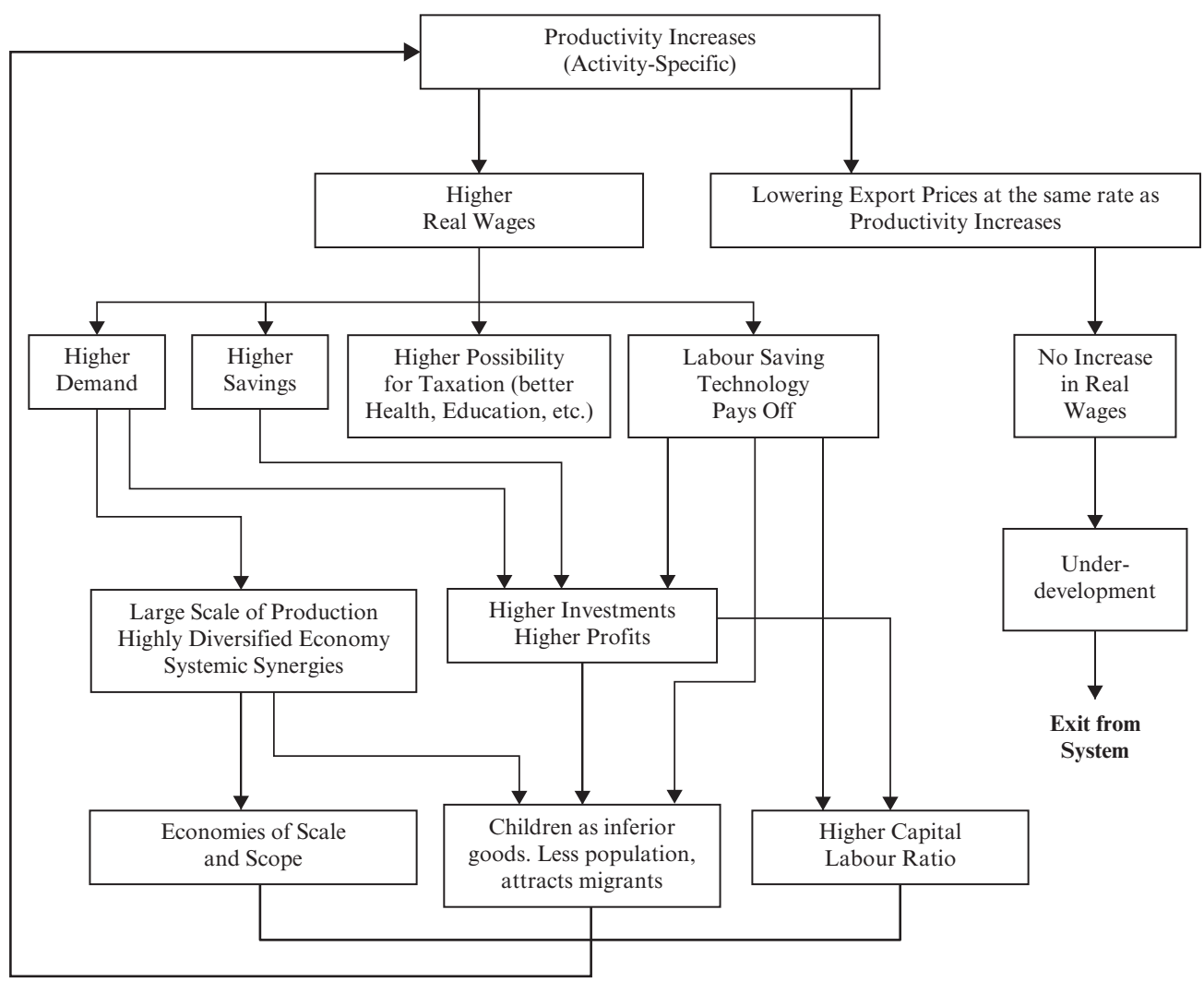

Source: Based on Reinert (1980, 39).

Figure 1.1 The virtuous circles of economic development: Marshall plans

sector. So the argument for 'manufacturing' should also be extended to increasing returns activities in the service sector.

\section{'THAT WRETCHED DIVISION OF LABOUR AND INCREASING RETURNS'}

If increasing and diminishing returns are so important in order to explain wealth and poverty, why has the question had so little impact on recent economic policy? The answer is twofold: first of all it was for a long time difficult to reconcile increasing and diminishing returns with the tools chosen by the economics profession. Peter Groenewegen, the celebrated historian of economic thought, titled a book chapter 'That wretched division of labour and increasing returns', explaining that the reason economists see 'increasing returns and the division of labour as wretched (is) because they play havoc with conventional notions of competition and equilibrium' (Groenewegen 2003, Vol. 1, 186). The second part of the answer no doubt lies in what Thorstein Veblen would have called 'the 


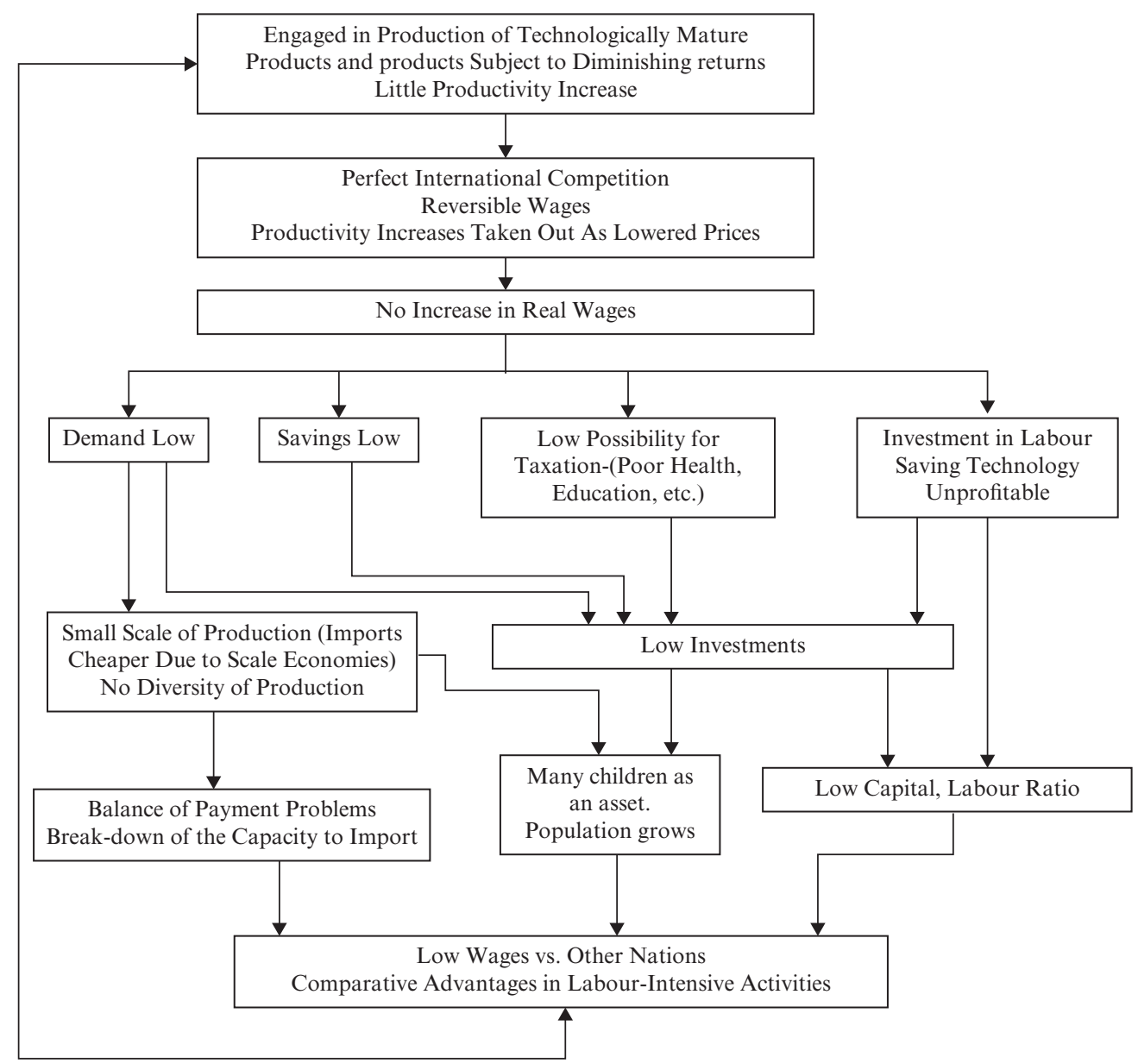

Source: Reinert 1980 p.41 (1)

Figure 1.2 The vicious circles of poverty: Morgenthau plans

vested interests': the vested interests of the industrialized West, at least short term, were to keep the Third World as suppliers of raw materials, as David Ricardo's trade theory opened up for. I emphasize short term, because in the long term, considering the number of refugees from de-industrialized countries, it would also be in the interest of the West to industrialize the poor world. In addition to stopping the flow of refugees, industrialization would boost global demand and create new customers for the West. ${ }^{52}$

52 This was in fact an argument used in the nineteenth-century US: England should not be jealous of US manufacturing, as this process would create a bigger demand for England than a US without a manufacturing industry could ever provide. Instead of exporting spades to the US, England would export machinery to manufacture spades. 
As Kenneth Arrow recognized in his introduction to W. Brian Arthur's book on Increasing Returns and Path Dependency in the Economy:

The concept of increasing returns has had a long but uneasy presence in economic analysis. The opening chapters of Adam Smith's Wealth of Nations put great emphasis on increasing returns to explain both specialization and economic growth. Yet the object of study moves quickly to a competitive system and a cost-of-production theory of value, which cannot be made rigorous except by assuming constant returns. The English school (David Ricardo, John Stuart Mill) followed the competitive assumptions and quietly dropped Smith's boldly-stated proposition that, 'the division of labor is limited by the extent of the market', division of labor having been shown to lead to increased productivity. (Arrow 1994, ix)

The increasing returns phenomenon, first described as an economic phenomenon by Antonio Serra, has led a perilous and marginal existence in economics because it is essentially incompatible with perfect competition and with equilibrium. Those who have tried to deal with the problem, like French mathematician and economist Cournot (1838), develop theories of monopoly and oligopoly. Formalizing Serra's model numerically is not a problem. This was done convincingly in 1923 by the Princeton economist Frank Graham (1923) (see the Appendix). The problem is that this key factor of determining the wealth and poverty of nations is not compatible with what has been selected as the key metaphor in economics: equilibrium.

In the twentieth century increasing returns were also discussed by Allyn Young in 1928, Edward Chamberlin and Joan Robinson in the 1930s, and then again by Nicholas Kaldor in the 1950s. But, as Kenneth Arrow puts it, 'this tradition acts like an underground river, springing to the surface only every few decades' (Arrow 1994).

The emphasis of authors who have recently 'rediscovered' increasing returns - such as Arthur (1994) in the context of technological change and path dependence, or Krugman (1991) in the context of geographical clustering and inter-regional trade - is that increasing returns are generated by positive feedback loops that magnify small initial conditions and thereby generate path dependence, whether of a technology or of a geographical location.

\section{PAUL KRUGMAN'S BRIEF FLIRTATION WITH SERRA'S DICHOTOMY}

'About a year ago I more or less suddenly realized that I have spent my whole professional life as an international economist thinking and writing about economic geography, without being aware of it' said Paul Krugman in a 1990 lecture which was later published as Geography and Trade (Krugman 1991, 1). In this volume, Krugman essentially explained - without quoting them - why the theoretical approaches of Giovanni Botero and Antonio Serra, whose main goal was to explain why wealth was geographically so unevenly spread, were not compatible with standard economic theory:

The neglect of spatial issues in economics arises for the most part from one simple problem: how to think about market structure. Essentially, to say anything useful or interesting about the location of economic activity in space, it is necessary to get away from the constant-returns, perfectcompetition approach that still dominates most economic analysis. As long as economists lacked 
the analytical tools to think rigorously about increasing returns and imperfect competition, the study of economic geography was condemned to lie outside the mainstream of the profession. Indeed, as standards of rigor in economics have risen over time, the study of location has been pushed further and further into the intellectual periphery.

Krugman correctly claimed that the reason scale effects were excluded was that the profession was unable to express them mathematically. Starting in 1979, Krugman published a series of articles introducing increasing returns in international trade theory. His 1979 and 1980 articles, reproduced in the volume cited, model a world where an initial discrepancy in capital-labour ratio exists between two countries or groups of countries. A period of increasing international trade follows, where only the industrial sector works under increasing returns to scale. The result of this is a world divided into two groups, a rich industrialized centre and a poor underdeveloped periphery. In these papers, Krugman referred approvingly to Myrdal, Frank, Baran, Wallerstein and even Lenin.

This breakthrough in international trade theory was the result of using models originating in the study of imperfectly competitive markets in the field of industrial economics. Krugman inadvertently opened a Pandora's box, where international markets are no longer fully competitive, but systematically asymmetrical (increasing versus diminishing returns) and where countries therefore may grow poorer in the presence of free trade than under autarky. Paradoxically, the wave of Reaganomics free market policies, which hit the developing countries in the 1980s, roughly coincided with the first proof of neoclassical trade theorists that government intervention really could improve the free trade situation of a poor country (Grossman 1992). Krugman's conclusions are no more precise than were Alfred Marshall's in 1890: that a country can be better off subsidizing its increasing returns activities and taxing those under diminishing returns (Marshall 1890, 448-449).

However, Krugman does not refer to Alfred Marshall. His history of increasing returns starts with Graham's 1923 article, ${ }^{53}$ and he has no mention of the long history of increasing returns - going back to Serra in 1613 - as a cause of imperfect competition and consequently as a factor determining economic policy, especially the support and protection of national industry.

Krugman's imaginative models have extended to 'a clever paper on interstellar trade, where goods are transported from one stellar system to another at speeds close to that of light; the resulting relativistic correction to time entails different interest rates in different frames of reference' (Dixit 1993). The problem in today's economic theory is that writing a model of a phenomenon proves next to nothing. Any good graduate student in economics can write a model showing their pet theory. The problem lies in verifying the models, and deciding which ones contain elements which point at important relationships in the real world. After siding with the dependency school, and with Lenin, in his 1979 and 1980 articles, Krugman has been sitting on the lid of the Pandora's box he opened. By the 1990s the asymmetrical aspects (Serra's increasing versus diminishing returns) of Krugman's work seem to disappear, to be substituted by a Ricardian model

53 The core of which is reproduced in the Appendix. 
Table 1.3 Economic characteristics that accompany increasing and diminishing returns

\begin{tabular}{|c|c|}
\hline $\begin{array}{l}\text { Characteristics of } \\
\text { Schumpeterian activities } \\
\text { (= 'good' export activities) }\end{array}$ & $\begin{array}{l}\text { Characteristics of } \\
\text { Malthusian activities. } \\
\text { (= 'bad' export activities if no Schumpeterian } \\
\text { sector present) }\end{array}$ \\
\hline Increasing returns & Diminishing returns \\
\hline $\begin{array}{l}\text { Dynamic imperfect } \\
\text { competition }\end{array}$ & $\begin{array}{l}\text { Perfect competition } \\
\quad \text { (commodity competition) }\end{array}$ \\
\hline Stable prices & Extreme price fluctuations \\
\hline Generally skilled labour & Generally unskilled labour \\
\hline Creates a middle class & Creates 'feudalist' class structure \\
\hline $\begin{array}{l}\text { Irreversible wages } \\
\text { ('stickiness' of wages) }\end{array}$ & Reversible wages \\
\hline $\begin{array}{l}\text { Technical change leads to higher wages } \\
\text { to the producer (Fordist wage regime) }\end{array}$ & $\begin{array}{l}\text { Technical change tends to lower price to } \\
\text { consumer }\end{array}$ \\
\hline $\begin{array}{l}\text { Creates large synergies } \\
\text { (linkages, clusters) }\end{array}$ & Creates few synergies \\
\hline
\end{tabular}

with increasing (but not diminishing) returns added. The new insights based on Serra's dichotomy of increasing versus diminishing returns were - inexplicably in my opinion lost. Krugman's 1979 and 1980 articles, which provided very important insights into the structure of North-South trade, appear to have been relegated to the same level as the interstellar paper: clever uses of mathematics with little or no practical consequences. In Table 1.3 I have put together a number of economic characteristics that accompany increasing and diminishing returns, respectively.

However, such qualitative differences between economic activities and between economic actors as are described in Figure 1.3 have effectively disappeared from the economics profession. As Nobel Laureate James Buchanan puts it: 'Any generalized prediction in social science implies at its basis a theoretical model that embodies elements of an equality assumption. If individuals differ, one from the other, in all attributes, social science becomes impossible' (Buchanan 1979, 231).

This writer would add that the same argument applies for economic activities. If they are different, the lack of 'mathiness' in conveying qualitative differences disqualifies such observations from 'serious science'. Alfred Marshall's idea of 'the representative firm' disqualifies the economics profession from seeing that the 'firm' of a 12-year old shoeshine boy in the slums of Lima is a very different creature from Bill Gates's Microsoft. Indeed, economic theory hails the market conditions of the former as 'normal' ('perfect competition') and the latter not. This blind spot has enormous consequences for our inability to eradicate poverty. 


\section{SERRA AND THE TECHNOLOGY OPTIMISM/TECHNOLOGY PESSIMISM DEBATE}

The 1972 book Limits to Growth (Meadows et al. 1972) marked a turning point in our understanding of the relationship between Planet Earth and its people. What is not so well known is that the following year a group of researchers - most of whom were based at the University of Sussex - produced a volume in response: Models of Doom: $A$ Critique of the Limits to Growth (Cole et al. 1973). The Sussex group's response to the Massachusetts Institute of Technology (MIT) model used in Limits to Growth was essentially 'Malthus in, Malthus out': any models based on diminishing returns - as that of Malthus - would produce very pessimistic results. Limits to Growth had underestimated the potential for technological change and increasing returns.

Since 1972 two camps seem to have formed, one of notorious technology pessimists and the other of notorious technology optimists. Mainstream economics, with its insistence on constant returns to scale, has not enlightened the debate between the two opposing camps. In a 2014 article in Futures (Mathews and Reinert 2014), John Mathews and I argued that the insights of Antonio Serra should be used in deciding when technology optimism and when technology pessimism is appropriate. The article also describes some of the industrial dynamics which result from a world dominated by increasing and diminishing returns and technological learning.

The paper uses the energy sector as an example, arguing for renewable energy based on the difference between extracting and harvesting energy. Extraction of fossil fuel takes place under diminishing returns, in a situation where technological change fights to counteract the fact that resources are increasingly costly to get at. Harvesting nature's renewable energy, on the other hand, is subject to no such limits. Costs per unit of extracted energy are bound to increase after a certain point, and this point has been reached long ago. Renewables, on the other hand, are harvested and manufactured - as are all manufactures - under conditions of increasing returns: costs tend to decrease with increased volume of production.

Increasing returns are also found when technology is held constant, that is, as production moves along the cost curve into higher volumes. But this phenomenon of falling costs is particularly important because cost curves tend to shift with new technologies. Plotting the actual cost of production over time gives us the learning curve. This curve describes how every time the quantity of units manufactured doubles, the number of direct labour hours tends to decrease at a uniform rate (Hirschman 1964; Reinert 1980). A related phenomenon, the experience curve, is found when total costs rather than only labour costs are imputed (Boston Consulting Group 1972; Reinert 1980).

Extracting oil from tar sands or gas from coal seams is what Klare (2012) calls 'extreme resources', in the sense that they are extremely difficult to extract, extremely dangerous and extremely dirty. Tar sands oil pollutes not just the land where it is extracted, but everything downstream as well - including, it would seem, the media.

The world of energy is only now discovering the key differences between manufacturing as a source of wealth (utilizing manufactured renewables), and resource extraction, which is subject to diminishing returns. As noted previously, while diminishing returns indeed give reason for pessimism, increasing returns make it possible to take a more optimistic view. US economist Erasmus Peshine Smith (1814-1882) was in a sense a 


\section{Handbook of alternative theories of economic development}

visionary of renewable energy when he argued: 'The entire universe then is motion, and the only point is how much of the universal and ceaseless motion we shall utilize, and how much we shall permit to be working against us' (Hudson 1968, 104).

In response to concerns over the future of the planet, many are calling for an end to economic growth, in the name of respecting ecological limits and finite planetary resources. The problem is that this concern is based on a misunderstanding of the character of economic growth. If it is extensive growth - that is, based on increasing resource throughput - then it is clear that it must one day come to a halt and be succeeded by a stationary state, if humans and life in general are to survive. But it is perfectly possible to have intensive growth: that is, growth in incomes without a corresponding growth in resource throughput. This is what is meant, in fact, by increasing returns: getting more out of what is put in. So capturing increasing returns means, essentially, embarking on a process of intensive growth; which if based on renewable energies (always available) and resource recirculation can be accurately called 'green growth'.

It is to be expected that new 'green' sectors like renewable energies and circular economy linkages (industrial symbiosis) will grow and propagate based on their capacity to generate synergies and increasing returns, in exactly the same way that Kaldor (1970) foresaw that regions based on manufacturing activities would flourish at the expense of regions locked into diminishing returns activities.

Scholars grapple with phrases or metaphors to describe this amazing reality, as in phrases like 'virtuous circles' or 'circular and cumulative causation', all of which are based on increasing returns or manufacturing multipliers. The best and most graphic phrase is that coined by Kaldor: increasing returns propagate through manufacturing value chains like a 'chain reaction', where each addition of an increasing return (multiplier) is based on earlier such multipliers. ${ }^{54}$ The greater the intensity of linkages secured, the greater the multiplier effect. This is the secret of the effectiveness of manufacturing clusters or industrial districts; or, in the case of green production, of eco-industrial clusters or parks.

Mainstream economics completely obscures this process with its relentless focus on equilibrium, perfect competition, constant returns to scale and the representative firm. All these concepts make sense only in a world abstracted from any resemblance to real business processes; which is why all the successful and wealthy countries today pursue strategies based on developmentalism and industry policy rather than purist free trade based on equilibrium reasoning.

\section{CONCLUSION}

If we look at the history of economic policy - rather than the history of economic ideas the record of the last 500 years of world economic history has been one of heavy-handed industrial policy favouring manufacturing over the production of raw materials. One

\footnotetext{
54 The notion of 'circular and cumulative causation' was introduced into economic reasoning by Myrdal, and was taken up by Kaldor (1970), as explained in detail by Toner (2000). Related concepts in the setting of development economics are the 'big push' (Rosenstein-Rodan) and balanced versus unbalanced growth (Nurkse, Hirschman). These issues are discussed in Chapter 19 in this volume, on classical development economists.
} 
aspect of this heavy-handed policy was the prohibition of manufacturing in Europe's colonies, an aspect which contributed to many colonial uprisings, including the independence movement of the United States.

From the point of view of economic textbooks, students of course get an entirely different picture. Free trade - 'doux commerce' - is being presented as the key to economic growth and welfare. However, going back to the historical record we find that only industrialized countries have ever made it into the club of the rich. ${ }^{55}$ The only exceptions here are countries living off petroleum rents, generally with a very skewed income distribution. So sweet commerce - 'doux commerce' - is clearly not the key to wealth, it is rather a much less poetic 'sweet increasing returns' or 'doux rendements d'échelle croissants'. In 1588 Giovanni Botero gave us the narrative explaining this, and in 1613 Antonio Serra added the key theoretical point: the key lies in what happens to a nation's production costs as production increases, that is, in increasing and diminishing returns to scale, and the resultant market conditions.

Hundreds of years of often extremely successful economic theory and policy under the labels 'mercantilism' and 'cameralism' - including the emergence of Europa and the US as world economic powerhouses - testify to Botero's and Serra's main points. While classical development economists may have argued about whether to adopt a gradual and balanced development or a big push, and while they may have argued about the importance of linkages and of the terms of trade, they all agreed with Serra that industrialization was a necessity. In classical development economics increasing returns were always the key argument for industrialization, and the 1947 Havana Charter ${ }^{56}$ (formally the Final Act of the United Nations Conference on Trade and Employment) allowed for nations to protect their manufacturing industry: (1) as long as their production was not at the production possibility frontier (that is, as long as there was unemployment); or (2) if the country had a plan for industrialization. With the victory of neoclassical economics other models took over and the World Bank started using models assuming full employment, even in countries like Haiti where a maximum of 20 per cent of the adult population have what one could define as a job.

Going back to Botero and Serra, however, we find that the key factor is not industry or manufacturing per se, it is the virtuous cumulative causations set in motion by increasing returns which, as already mentioned, may also be found in the service sector. However, a country based on the export of raw materials is unlikely to develop large demand for advanced service products, so the industrial sector is still needed.

As Groenewegen noted, the increasing returns Serra first described are 'wretched' because this very real fact of everyday life is fundamentally incompatible with the main metaphor upon which the economics profession has chosen to construct its edifice equilibrium - and the standard assumption of constant returns to scale. In an economy where all production takes place with constant returns to scale over all ranges of output for all goods, there would be no trade at all (except presumably in raw materials). Each

\footnotetext{
55 Vries (2013) makes this same point, as does (as already mentioned) former World Bank Chief Economist Justin Lin (2012). Even the World Bank Chief Economist admits to Serra's point, and to the theories of classical development economics, but this insight hardly influences the policies of the World Bank or the Washington institutions in general.

56 See chapter 15 in this volume.
} 
person would become 'a microcosm of the whole society', as James Buchanan puts it (Buchanan 1979, 236). And as a new 'anti-textbook' of economics hammers in: 'all factors can earn their marginal product only if there are constant returns to scale' (Hill and Myatt 2010, 180).

We are faced with the fundamental paradox that under the standard assumptions underlying Paul Samuelson's proof that free trade will tend to lead to the equalization of world wages - perfect information and constant returns to scale - all trade of manufactured goods would cease to exist. Every individual on Earth would be completely self-sufficient in everything but raw materials. In order to explain why trade exists at all, we have to introduce factors that violate the assumptions which prove that we shall all be equally rich if we only let free trade be the governing principle of the world economic order. The very factors which cause international trade are the very same reasons that we live in a world where economic development is uneven. Two fundamental factors at work here are the dynamic and cumulative effects of Serra's innovations: diminishing and increasing returns to scale, respectively leading to perfect and imperfect competition.

Almost six decades ago development economist and Nobel Laureate Gunnar Myrdal foresaw that:

within the next ten or twenty years the now fashionable highly abstract analysis of conventional economists will lose out. Though its logical base is weak - it is founded on utterly unrealistic, poorly scrutinized, and rarely even explicitly stated assumptions - its decline will mainly be an outcome of the tremendous changes which, with crushing weight, are falling upon us. (Myrdal $1976,88)$

It is indeed likely that Myrdal was wrong only about the timing. Just as physiocratic theory - in all practical matters - lost its lustre after the famines caused by speculations and excessively 'free markets' leading up to the French Revolution (Kaplan 2015 [1976]), and David Ricardo lost out in the theoretical battle after 1848, today's abstract theory is likely to lose ground. However, the moves to build alternative theories based on the cumulative causations set in motion by increasing and diminishing returns are not widespread..$^{57}$

Regardless of what happens to economic theory, in real life increasing and diminishing returns are going to play key roles in determining the wealth and poverty of nations. In which technological and economic contexts these two factors are going to develop is an open question. On the one hand we find a tendency towards extreme cases of increasing returns where information technology has opened up for production and distribution at marginal costs which are close to zero. This may result in extreme concentration of wealth and power, economically and politically, especially as the climate for establishing a global antitrust organization is extremely weak. ${ }^{58}$

On the positive - decentralizing - side, three-dimensional (3D) printing might become part of a process of 'distributed manufacturing' which counteracts the traditional industrial paradigm based on economies of scale and cheap transport. Another possible 
development is 'commons-based peer production', also called 'social production'. These terms describe a new model of socio-economic production in which the creative energy of large numbers of people is coordinated (usually with the aid of the Internet) into large projects without traditional hierarchical organization. Wikipedia, Facebook and YouTube are examples of such peer production, creating economies of scope (in a shared infrastructure) rather than economies of scale. So - in a somewhat paradoxical way - the hugely increasing returns to scale in information technology as a generic infrastructure technology seem also to lead to huge potentials for decentralization and less reliance on increasing returns in the final stages of production.

In whatever way the future balance of increasing and diminishing returns may play out, it is increasingly obvious that the continuing marginalization - even disregard - of Antonio Serra's great contribution to the science of economics is very costly both in terms of scientific relevance and in terms of our ability to eradicate world poverty.

\section{REFERENCES}

Acemoglu, Daron and James Robinson (2012), Why Nations Fail: The Origins of Power, Prosperity, and Poverty, London: Profile Books.

Alberti, Leon Battista (1734), Trattato del Governo della Famiglia, Florence: Tartini \& Franchi.

Arthur, W. Brian (ed.) (1994), Increasing Returns and Path Dependency in the Economy, Ann Arbor, MI: University of Michigan Press,

Arrow, Kenneth (1994), 'Introduction', in W. Brian Arthur (ed.), Increasing Returns and Path Dependency in the Economy, Ann Arbor, MI: University of Michigan Press, p. ix.

Assandra, Giuseppe (1926/1928), 'Giovanni Botero. Note biografiche e bibliografiche di Giuseppe Assandra suo concittadino' (ed. Gino Borghezio), in Bollettino storico-bibliografico subalpino, XXVIII, Turin, 1926, pp. 407-442, and XXX, 1928, pp. 29-63, 307-351.

Baade, Fritz (1955), 'Gruß und Dank an Herbert Hoover', Weltwirtschaftliches Archiv, 74(1), 1-6.

Bain, Joe S. (1956), Barriers to New Competition: Their Character and Consequences in Manufacturing Industries, Cambridge, MA: Harvard University Press.

Baron, Hans (1938), 'Franciscan Poverty and Civic Wealth as Factors in the Rise of Humanist Thought', Speculum, 13, 1-37.

Bentham, Jeremy (1780), An Introduction to the Principles of Morals and Legislation, London: University Paperback.

Berch, Anders (1747), Inledning til Almänna Hushålningen, innefattande Grunden til Politie, Oeconomie och Cameralwetenskaperna, Stockholm: Lars Salvius.

Berger, Sebastian (2009), The Foundations of Non-Equilibrium Economics: The Principle of Circular and Cumulative Causations, London: Routledge.

Bolt, Jutta and Jan Luiten Van Zanden (2014), 'The Maddison Project: Collaborative Research on Historical National Accounts', Economic History Review, 67(3), 627-651.

Boston Consulting Group (1972), Perspectives on Experience, Boston, MA: BCG.

Botero, Giovanni (1589), Della ragion di stato libri dieci: con tre libri delle cause della grandezza, e magnificenza delle città, Venice: Appresso i Gioliti.

Botero, Giovanni (1599), Le relationi universali di Giovanni Botero Benese, divise in quattro parti. . . Nuouamente aggiuntaui la descrittione del mare, Venice: Appresso Giorgio Angelieri.

Botero, Giovanni (1635), The Cause of the Greatnesse of Cities. Three Bookes, With Certaine Observations concerning the Sea. Written in Italian by John Botero . . . London: Printed by E.P. for Henry Seile.

Botero, Giovanni (2012), On the Causes of the Greatness and Magnificence of Cities, transl. and with an Introduction by Geoffrey W. Symcox, Toronto: University of Toronto Press.

Bouwsma, William James (2000), The Waning of the Renaissance, 1550-1640, New Haven, CT: Yale University Press.

Braudel, Fernand (1975), Capitalism and Material Life 1400-1800, New York, USA and London, UK: Harper \& Row.

Braudel, Fernand (1982), On History, Chicago, IL: University of Chicago Press.

Braudel, Fernand (1991), Out of Italy: 1450-1650, Paris: Flammarion. 


\section{Handbook of alternative theories of economic development}

Browne, Thomas (1643), Religio Medici, London: Andrew Crooke.

Bruni, Leonardo, (1987), The Humanism of Leonardo Bruni: Selected Texts, translated and edited by Gordon Griffiths, James Hankins and David Thompson, Binghamton, NY: Medieval and Renaissance Texts and Studies/ Renaissance Society of America.

Buchanan, James (1979), What Should Economists Do? Indianapolis, IN: Liberty Press.

Buck, Philip (1942), The Politics of Mercantilism, New York: Henry Holt.

Bullock, Charles J. (1939), The Vanderblue Collection of Smithiana, Boston, MA: Baker Library, Harvard Graduate School of Business Administration.

Burkhardt, Johannes and Birger Priddat (2000), Geschichte der Ökonomie, Frankfurt: Deutsche Klassiker Verlag.

Cole, H.S.D. et al. (1973), Models of Doom. A Critique of the Limits to Growth, New York: Universe Books.

Cournot, Antoine Augustin (1838), Recherches sur les principes mathématiques de la théorie des richesses, Paris: Hachette.

De Luca, Mario (1968), Gli economisti napoletani del settecento e la politica dello sviluppo, Naples: Morano Editore.

Descendre, Romain (2009), L'État du Monde; Giovanni Botero entre Raison d'État et géopolitique, Geneva: Droz.

Diamond, Jared (1997), Guns, Germs, and Steel: The Fates of Human Societies, New York: Norton.

Dixit, Avinash (1993), 'In Honor of Paul Krugman: Winner of the John Bates Clark Medal', Journal of Economic Perspectives, 7(2), 173.

Fanfani, Amintore (1955), Storia delle dottrine economiche dall'antichità al XIX secolo, Milan: Giuseppe Principato.

Finkelstein, Andrea (2000), Harmony and the Balance: an Intellectual History of Seventeenth-Century English Economic Thought, Ann Arbor, MI: University of Michigan Press.

Firpo, Luigi (1971), 'Botero, Giovanni', in Dizionario Biografico degli Italiani, Vol. 13, http://www.treccani.it/ enciclopedia/giovanni-botero_(Dizionario-Biografico).

Firpo, Luigi (1975), 'La "Ragion di Stato" di Giovanni Botero: redazione, rifacimenti, fortuna', in Gianrenzo Clivio and Riccardo Massano (eds), Civiltà del Piemonte. Studi in onore di Renzo Gandalfo nel suo settantacinquesimo compleanno, Vol. I, Turin: Centro Studi Piemontesi, pp. 139-164.

Goldthwaite, Richard (2009), The Economy of Renaissance Florence, Baltimore, MD: Johns Hopkins University Press.

Grafton, Anthony (2000), Leon Battista Alberti. Master Builder of the Italian Renaissance, New York: Hill \& Wang.

Graham, Frank (1923), 'Some Aspects of Protection Further Considered', Quarterly Journal of Economics, 37 , 199-227.

Groenewegen, Peter D. (2003), Classics and Moderns in Economics, Vol. 1, New York, USA and London, UK: Routledge.

Grossman, Gene (ed.) (1992), Imperfect Competition and International Trade, Cambridge, MA: MIT Press.

Hamilton, Alexander (1791), Report of the Secretary of the Treasury of the United States, on the Subject of Manufactures: Presented to the House of Representatives, December 5, 1791. Philadelphia, PA: Childs \& Swaine.

Hausmann, Ricardo and Cesar Hidalgo (2014), The Atlas of Economic Complexity. Mapping Paths to Prosperity, Cambridge, MA: MIT Press.

Hill, Rod and Tony Myatt (2010), The Economics Anti-Textbook. A Critical Thinker's Guide to Microeconomics, Halifax: Firewood Publishing and London: Zed Books.

Hirschman, Albert O. (1977), The Passions and the Interests. Political Arguments for Capitalism before its Triumph, Princeton, NJ: Princeton University Press.

Hirschman, W. (1964), 'Profit from the Learning Curve', Harvard Business Review, 42, 125-139.

Hudson, Michael (1968), 'E. Peshine Smith: A Study in Protectionist Growth Theory and American Sectionalism', PhD thesis, New York University.

Isocrates (355 BC), 'On the Peace', Verse 19 in Isocrates with an English Translation in Three Volumes, ed. George Norlin (1984), Cambridge, MA: Harvard University Press.

Issawi, Charles (ed.) (1987), An Arab Philosophy of History. Selections from the Prolegomena of Ibn Khaldun of Tunis (1332-1406), Princeton, NJ: Darwin Press.

Kaldor, Nicholas (1970), 'The Case for Regional Policies', Scottish Journal of Political Economy, 17, 337-348.

Kaplan, Steven L. (2015 [1976]), Bread, Politics and Political Economy in the Reign of Louis XV, 2nd edn, London: Anthem.

Kazhdan, Alexander (1991), The Oxford Dictionary of the Byzantium, New York: Oxford University Press.

Klare, M.T. (2012), The Race for What's Left: The Global Scramble for the World's Last Resources, New York: Metropolitan Books.

Koyré, Alexandre (1957), From the Closed World to the Infinite Universe, Baltimore, MD: Johns Hopkins Press. 
Krugman, Paul (1991), Geography and Trade, Cambridge, MA: MIT Press.

Kuhn, Thomas S. (1970), The Structure of Scientific Revolutions, Chicago, IL: University of Chicago Press.

Lin, Justin Yifu (2012), New Structural Economics: A Framework for Rethinking Development and Policy, Washington, DC: World Bank Publications.

List, Friedrich (1841), Das nationale System der politischen Ökonomie, Stuttgart: J.G. Cotta'scher Verlag.

Lüdtke, Wilhelm (1939), 'Veit Ludwig von Seckendorff, ein deutscher Staatsmann und Volkserzieher des 17. Jahrhunderts', Jahrbücher der Akademie gemeinnütziger Wissenschaften zu Erfurt, 54, 39-138.

Luther, Martin (2015), On Commerce and Usury (1524), ed. with Introduction and notes by Philipp Robinson Rössner, London: Anthem.

Malthus, Thomas (1798), An Essay on the Principle of Population, London: J. Johnson.

Malynes, Gerhard (1622), The Maintenance of Free Trade, According to the three essentiall (sic) Parts ... Commodities, Moneys and Exchange of Moneys, London: William Sheffard.

Malynes, Gerhard (1623), The Center of the Circle of Commerce, or, A Refutation of a Treatise,....,lately published by E.M., London: Nicholas Bourne.

Marshall, Alfred (1890), Principles of Economics, London: Macmillan.

Marx, Karl and Friedrich Engels (1848), Manifesto of the Communist Party, Claremont: Joshua James Press.

Maryks, Robert Alexander (2008), Sant Cicero and the Jesuits, The Influence of the Liberal Arts on the Adoption of Moral Probabilism, Aldershot: Ashgate.

Mathews, John and Erik S. Reinert (2014), 'Renewables, Manufacturing and Green Growth: An Energy Strategy Based on Capturing Increasing Returns', Futures, 61, 13-22.

Meadows, Donella H., Dennis L. Meadows, Jørgen Randers and William W. Behrens III (1972), Limits to Growth, New York: Universe Books.

Meek, Ronald (1976), Social Science and the Ignoble Savage, Cambridge: Cambridge University Press.

Meinecke, Friedrich (1925), Die Idee der Staatsräson in der neueren Geschichte, 2nd edn, Munich: Oldenbourg.

Mill, John Stuart (1848), Principles of Political Economy, London: Longmans.

Misselden, Edward (1622), Free Trade and the Meanes to Make Trade Flourish, London: Simon Waterson.

Misselden, Edward (1623), The Circle of Commerce or the Ballance of Trade, London: Nicholas Bourne.

Montaigne, Michel de (1958 [1580]), Essays, London: Penguin Books.

Mun, Thomas (1664), England's Treasure by Forraign Trade, London: J.G. for Thomas Clark.

Myrdal, Gunnar (1976), 'The Meaning and Validity of Institutional Economics', in Kurt Dopfer (ed.), Economics of the Future: Towards a New Paradigm, London: Macmillan, pp. 82-89.

Ortiz de Zúñiga, Iñigo (1967/1972), Visita de la Provincia de León de Huánuco en 1562, 2 vols, ed. John V. Murra, Huánuco, Perú: Universidad Nacional Hermilio Valdizán, Facultad de Letras y Educación.

Paracelsus (1951), [Paracelsus] Hohenheim, Aureolus Theophrastus Bombastus von, 'Man in the Cosmos', in Jolande Jacobi (ed.), Selected Writings of Paracelsus, Princeton, NJ: Princeton University Press, pp. 39-45.

Patalano, Rosario and Sophus A. Reinert (eds) (2016), Antonio Serra and the Economics of Good Government, London: Palgrave.

Popper, Karl Raimund (1957), The Poverty of Historicism, London: Routledge \& Kegan Paul.

Raleigh, Sir Walter (1751), The Works of Sir Walter Raleigh, Kt. Political, Commercial, and Philosophical; Together With His Letters and Poems. . ., ed. Thomas Birch, London: Printed for R. Dosley.

Ranke, Leopold von (2013 [1833]), Savonarola, Bremen: Dearbooks.

Reinert, Erik S. (1980), 'International Trade and the Economic Mechanisms of Underdevelopment', PhD thesis, Cornell University.

Reinert, Erik S. (2000a), 'Full Circle: Economics from Scholasticism through Innovation and back into Mathematical Scholasticism. Reflections around a 1769 Price Essay: "Why is it that Economics so Far has Gained so Few Advantages from Physics and Mathematics?"', Journal of Economic Studies, 27(4-5), 364-376. Available at http://www.othercanon.org/papers/.

Reinert, Erik S. (2000b), 'Karl Bücher and the Geographical Dimensions of Techno-Economic Change', in Jürgen G. Backhaus (ed.), Karl Bücher: Theory - History - Anthropology - Non-Market Economies, Marburg: Metropolis, pp. 177-222.

Reinert, Erik S. (2005), 'A Brief Introduction to Veit Ludwig von Seckendorff (1626-1692)', European Journal of Law and Economics, 19, 221-230.

Reinert, Erik S. (2007), How Rich Countries Got Rich ... And Why Poor Countries Stay Poor, London: Constable.

Reinert, Erik S. (2009), 'Johann Heinrich Gottlob von Justi (1717-1771): The Life and Times of an Economist Adventurer', in Jürgen Backhaus (ed.), The Beginnings of Political Economy: Johann Heinrich Gottlob von Justi, New York: Springer, pp. 33-74.

Reinert, Erik S. (2012), Economics and the Public Sphere: The Rise of Esoteric Knowledge, Refeudalization, Crisis and Renewal', paper presented for The Public Mission of the Social Sciences and Humanities: 
Transformation and Renewal, Social Science Research Center Berlin (WZB), Berlin, Available at http://publicsphere.ssrc.org/reinert-economics-and-the-public-sphere/ (accessed 25 September 2015).

Reinert, Erik S. (2016), 'Antonio Serra and the Problems of Today', in Patalano, Rosario and Sophus A. Reinert (eds), Antonio Serra and the Economics of Good Government, London: Palgrave.

Reinert, Erik S. and Kenneth Carpenter (2016), 'German Language Bestsellers before 1850: Also Introducing Giovanni Botero as a Common Reference Point of Cameralism and Mercantilism', in Philipp Rössner (ed.), Economic Growth and the Origins of Modern Political Economy: Economic Reasons of State, 1500-2000, London: Routledge.

Reinert, Erik S. and Arno Mong Daastøl (1997), 'Exploring the Genesis of Economic Innovations: The Religious Gestalt-Switch and the Duty to Invent as Preconditions for Economic Growth', European Journal of Law and Economics, 4(2-3), 233-283.

Reinert, Erik S. and Francesca Viano (eds) (2012), Thorstein Veblen: Economist for an Age of Crises, London: Anthem.

Reinert, Erik S. and Ting Xu (2013), 'Declining Diversity and Declining Societies: China, the West, and the Future of the Global Economy', Working Paper Series 2-13-2, Musashi University, Tokyo, available at http:// www.unotheory.org/files/2-13-3.pdf.

Reinert, Sophus A. (2005), 'Cameralism and Commercial Rivalry: Nationbuilding through Economic Autarky in Seckendorff's 1665 Additiones', European Journal of Law and Economics, 19, 271-286.

Reinert, Sophus A. (2011), Translating Empire, Cambridge, MA: Harvard University Press.

Reinert, Sophus A. (2015), 'The Way to Wealth Around the World: Benjamin Franklin and the Globalization of American Capitalism', American Historical Review, 120(1), 61-97.

Roscher, Wilhelm (1868), 'Der sächsische Nationalökonom Johann Heinrich Gottlob von Justi', in Archiv für die Sächsische Geschichte, Vol. 6, 76-106.

Roversi, Giancarlo (ed.) (1989), Le Torri di Bologna. Quando, come e perché, Bologna: Grafis Edizioni.

Rubies, Joan-Pau (2000), Travel and Ethnology in the Renaissance, Cambridge: Cambridge University Press.

Samuelsson, Kurt (1964 [1957]), Religion and Economic Action, a Critique of Max Weber, New York: Harper \& Row; first published (1957), Ekonomi och Religion, Malmø: Kooperativa Förbundets Bokförlag (in Swedish).

Schefold, Bertram et al. (1995), Nicolaus Oresmus und sein 'Tractatus de origine et natura, iure \& mutationibus monetarum', Düsseldorf: Verlag Wirtschaft und Finanzen.

Schumpeter, Joseph (1954), History of Economic Analysis, New York: Oxford University Press.

Sebregondi, Ludovica and Tim Parks (2011), Money and Beauty. Bankers, Botticelli, and the Bonfire of the Vanities, Florence: Giunti.

Selwyn, Jennifer D. (2004), A Paradise Inhabited by Devils. The Jesuits' Civilizing Mission in Early Modern Naples, Aldershot: Ashgate Publishing.

Serra, Antonio (2011 [1613]), A 'Short Treatise' on the Wealth and Poverty of Nations (1613), ed. Sophus A. Reinert, London: Anthem.

Smith, Adam (1776), An Inquiry into the Nature and Causes of the Wealth of Nations, London: W. Strahan \& T. Cadell.

Sombart, Werner (1913), Der Bourgeois: Zur Geistesgeschichte des Modernen Wirtschaftsmenschen, Munich: Duncker \& Humblot, published in English (1915) as The Quintessence of Capitalism: a Study of the History and Psychology of the Modern Business Man, New York: E.P. Dutton.

Sombart, Werner (forthcoming 2016 [1916]), Modern Capitalism (1916), Erik S. Reinert, Philipp Rössner and Jürgen Backhaus (eds), London: Anthem.

Sombart, Werner (1929), Die drei Nationalökonomien, Munich: Duncker \& Humblot.

Soros, George (2002), George Soros on Globalization, New York: Public Affairs.

Spence, Jonathan D. (1983), The Memory Palace of Matteo Ricci, London: Penguin.

Stiglitz, Joseph E. and members of a UN Commission of Financial Experts (2010), Reforming the International Monetary and Financial Systems in the Wake of the Global Crisis (The Stiglitz Report), New York: New Press.

Symcox, Geoffrey (2012), 'Introduction', to Giovanni Botero, On the Causes of the Greatness and Magnificence of Cities, Toronto: University of Toronto Press, pp. xi-xxxvii.

Tawney, Richard (1926), Religion and the Rise of Capitalism: A Historical Study, London: J. Murray.

Tirole, Jean (1982), The Theory of Industrial Organization, Cambridge, MA: MIT Press.

Toner, Philip (2000), Main Currents in Cumulative Causation: The Dynamics of Growth and Development, London: Palgrave Macmillan.

Uztáriz, Geronimo de (1751), The Theory and Practice of Commerce and Maritime Affairs, Vol. 1, London: John \& James Rivington.

Vries, Peer (2012), 'Does Wealth Entirely Depend on Inclusive Institutions and Pluralist Politics?', The Other Canon Foundation and Tallinn University of Technology Working Papers in Technology Governance and Economic Dynamics, No. 43.

Vries, Peer (2013), Escaping Poverty, Vienna: University of Vienna Press. 
Weber, Max (1904/1905), 'Die protestantische Ethik und der Geist des Kapitalismus', Archiv für Sozialwissenschaften, Vol. XX, No. 1 (1904), pp. 1-54, and Vol. XXI, No. 1 (1905), pp. 1-110.

Weber, Max (1920). Gesammelte Aufsätze zur Religionssoziologie. 1, Die protestantische Ethik und der Geist des Kapitalismus, Tübingen: Mohr.

Weinstein, Donald (2011), Savonarola: The Rise and Fall of a Renaissance Prophet, New Haven, CT, USA and London, UK: Yale University Press.

Westbeck, Gustaf (1747), 'Tankeförsök om Särskilda Näringars Idkande', thesis, Uppsala.

Wolff, Christian (1750), The Real Happiness of a People under A Philosophical King Demonstrated; Not only from the Nature of Things, but from the undoubted Experience of the Chinese under their first Founder Fohi, and his Illustrious Successors, Hoam Ti, and Xin Num, London: Printed for M. Cooper, at the Globe.

Wood, Diana (2002), Medieval Economic Thought, Cambridge: Cambridge University Press.

Young, Allyn A. (1928), 'Increasing Returns and Economic Progress', Economic Journal, 38, 527-542.

\section{APPENDIX: FRANK GRAHAM'S DYNAMIC THEORY OF UNEVEN DEVELOPMENT BASED ON INCREASING AND DIMINISHING RETURNS}

Source: Graham (1923), reproduced in Reinert (2007, pp. 309-310).

STAGE 1: World Income and its Distribution before Trade

\begin{tabular}{|c|c|c|c|c|c|c|c|}
\hline \multicolumn{4}{|l|}{ Country A } & \multicolumn{4}{|l|}{ Country B } \\
\hline Man-days & $\begin{array}{l}\text { Output per } \\
\text { man-day }\end{array}$ & Productic & & Man-days & $\begin{array}{l}\text { Output per } \\
\text { man-day }\end{array}$ & Productic & \\
\hline 200 & 4 & wheat & 800 & 200 & 4 & wheat & 800 \\
\hline 200 & 4 & watches & 800 & 200 & 3 & watches & 600 \\
\hline
\end{tabular}

World production: 1600 wheat +1400 watches. In wheat equivalents: 3200

Country A's income in wheat equivalents: 1714 wheat

Country B's income in wheat equivalents: 1486 wheat

Price: 4 wheat $=3.5$ watches

STAGE 2: World Income and its Distribution after Each Country Specializes According to Its Comparative Advantage

\begin{tabular}{lllllllll}
\hline Country A & & & & Country B & & \\
\cline { 1 - 2 } Man-days & $\begin{array}{l}\text { Output per } \\
\text { man-day }\end{array}$ & Production & & Man-days & $\begin{array}{l}\text { Output per } \\
\text { man-day }\end{array}$ & Production \\
\hline 100 & 4.5 & wheat & 450 & 300 & 3.5 & wheat & 1050 \\
300 & 4.5 & watches & 1350 & 100 & 2 & watches & 200 \\
\hline
\end{tabular}

World production w. trade: 1500 wheat +1550 watches. In wheat equivalents: 3271

Country A's income in wheat equivalents: 1993 wheat

Country B's income in wheat equivalents: 1278 wheat

Conclusion: the country which specialized in the economic activity subject to diminishing returns grew poorer than it had been before trade. The opposite happened to the country specializing in increasing returns activities. 